\title{
SPELEOGENESIS OF THE "BUCO DEI VINCHI" INACTIVE SWALLOW HOLE (MONTE CROARA KARST SUB-AREA, BOLOGNA, ITALY), AN OUTSTANDING EXAMPLE OF ANTIGRAVITATIVE EROSION (OR "PARAGENESIS") IN SELENITIC GYPSUM. AN OUTLINE OF THE "POST-ANTIGRAVITATIVE EROSION”
}

\author{
SPELEOGENEZA FOSILNEGA PONORA "BUCO DEI VINCHI" \\ (MONTE CROARA, BOLONJA, ITALIJA), KOT IZJEMEN PRIMER PARAGENEZE \\ V SELENITU
}

\author{
Giancarlo PASINI ${ }^{1}$
}

\begin{abstract}
UDC 551.435.8(450.451)

Giancarlo Pasini: Speleogenesis of the "Buco dei Vinchi" inactive swallow hole (Monte Croara karst sub-area, Bologna, Italy), an outstanding example of antigravitative erosion (or "paragenesis") in selenitic gypsum. An outline of the "postantigravitative erosion"

Inactive swallow hole Buco dei Vinchi developed along a plane dividing selenitic gypsum stratum and an underlying shale interlayer, mostly by antigravitative erosion and by post-antigravitative erosion. It formed through six speleogenetic phases starting from a phreatic phase followed by several antigravitative erosion (= paragenetic) and post-antigravitative erosion phases and vadose phase. During first antigravitative erosion phase, the phreatic protoconduits evolved into small antigravitative conduits with typical cross-section in shape of an inversed $U$ or a bulb. At the end of this phase the small antigravitative conduits converged and merged together in successive stages to form ever-bigger conduits, until - at a certain point - most of them flowed into a single, much wider antigravitative conduit, which later evolved into a composite conduit. We demonstrate that the subhorizontal flat ceilings are not a characteristic feature of the antigravitative passages tout court - as claimed by most authors -, but instead they evolved in caves during periods when the piezometric surface was tangent to the vault of the cave (post-antigravitative erosion phenomenon). Thus these flat ceilings are traces of 'paleo-piezometric surfaces'; moreover these flat ceilings, being sub-horizontal originally, can provide important information on possible tectonic movements or breakdowns occurred after their formation. The possible ages of the karstic phenomena in the selenitic gypsum near Bologna are discussed. This paper points out that the Buco dei Vinchi and the Cava a Filo swallow holes,
\end{abstract}

\author{
Izvleček \\ UDK 551.435.8(450.451) \\ Giancarlo Pasini: Speleogeneza fosilnega ponora "Buco dei \\ Vinchi" (Monte Croara, Bolonja, Italija), kot izjemen primer \\ parageneze $v$ selenitu.
}

Buco dei Vinchi je fosilna ponorna jama nastala ob stiku med skrilavcem in sadro. Razvoj jame se je začel v freatičnih pogojih, nadaljeval skozi več paragenetskih in post-paragenetskih faz in končal $z$ vadozno fazo. Tekom prve paragenetsake faze so se freatični protokanali preoblikovali v paragenetske kanale s presekom v obliki obrnjenih črk $\mathrm{U}$ in $\Omega$. Ob koncu te faze je prišlo do postopnega združevanja manjših kanalov v večje kanale in končno $\mathrm{v}$ en sam velik paragenetski kanal, ki se je preoblikoval tudi v kasnejših fazah. V članku trdimo, da ravni subhorizontalni stropi niso znak navadne parageneze, ampak so nastali v obdobju, ko je bila piezometrična površina tangencialna na obok jame (post parageneza). Torej so ravni stropi kazalci nivoja nekdanje gladine postalnice. Glede na to, da so bili ob nastanku ti stropi subhorizontalni, nagnjeni stropi kažejo na tektonske premike $\mathrm{v}$ času po njihovem nastanku. Buco dei Vinchi in bližnji ponor Cava a Filosta, sta bila ob nastanku topografsko precej nižje kot sedaj. Opažanja kažejo, da se je proces inverzije reliefa začel pred vsaj 127.000 leti, začetek prvih kraških pojavov na območju Bolonje pa je še precej starejši. V članku obravnavamo absolutno nižanje nadmorske višine krasa na območju Monte Croare in to ocenjujemo na približno $0,39 \mathrm{~mm} /$ leto

Ključne besede: speleogeneza, parageneza, post-parageneza, stropni kanali, selenitni mamelon.

\footnotetext{
${ }^{1}$ Istituto di Scienze Marine (I.S.MAR.), Geologia Marina, del Consiglio Nazionale delle Ricerche (C.N.R.), Bologna (Italy) Istituto Italiano di Speleologia (Sezione dell'Istituto di Geologia e Paleontologia dell'Università di Bologna Alma Mater Studiorum, Italy) - Società Speleologica Italiana - Gruppo Speleologico Bolognese - Unione Speleologica Bolognese; Postal address: Via Ranzani 13/5, 40127 Bologna, Italy; tel.: +3951242120, e-mail: giancarlopasini@alice.it
} 
presently located in "topographic highs", were very probably in "topographic lows" at the time of their hydrologic activity, and that this is evidence of a relief inversion started at least 127,000 years ago. Therefore the beginning of the first karstic phenomena in the Bologna karst area is much older than this date. It is explained why the absolute altimetrical lowering of the Monte Croara karst sub-area (with respect to the present sea level) should be of about $-0.39 \mathrm{~mm} /$ year.

Keywords: speleogenesis, antigravitative erosion paragenesis, post-antigravitative erosion, ceiling channel, selenitic mamelon.

\section{FOREWORD}

I choose to take up the study of the small Buco dei Vinchi inactive swallow hole because it is certainly one of the oldest caves of the Bologna karst area, formed before an important relief inversion which was noticed also by Forti (2003, pp. 248) (see chapter "The relief inversion in the Monte Croara karst sub-area").

The antigravitative passages (also named incorrectly "paragenetic passages": see Pasini 2009) - together with the isolated vadose entrenchments and the bypass tubes
- have been considered until now as minor gradational details in the development of certain caves (Ford 2000, 5.3 Fig. 3; Ford \& Williams 2007, pp. 232 - Fig. 7.19). On the contrary, the Buco dei Vinchi cave (as many others of the more than 200 gypsum caves - up to $11 \mathrm{~km}$ long - of the Bologna karst area, not yet studied in detail) was largely developed just thanks to the process of the antigravitative erosion (or paragenesis), well-known since 1942 (Bretz 1942).

\section{LOCATION AND DESCRIPTION OF THE BUCO DEI VINCHI CAVE}

The entrance of the Buco dei Vinchi cave is located in the "Parco Naturale Regionale dei Gessi Bolognesi e Calanchi
dell'Abbadessa" (Fig. 1) at $193 \mathrm{~m}$ a.s.l., at the bottom of a small doline (Dolina dei Vinchi). Both the doline and the

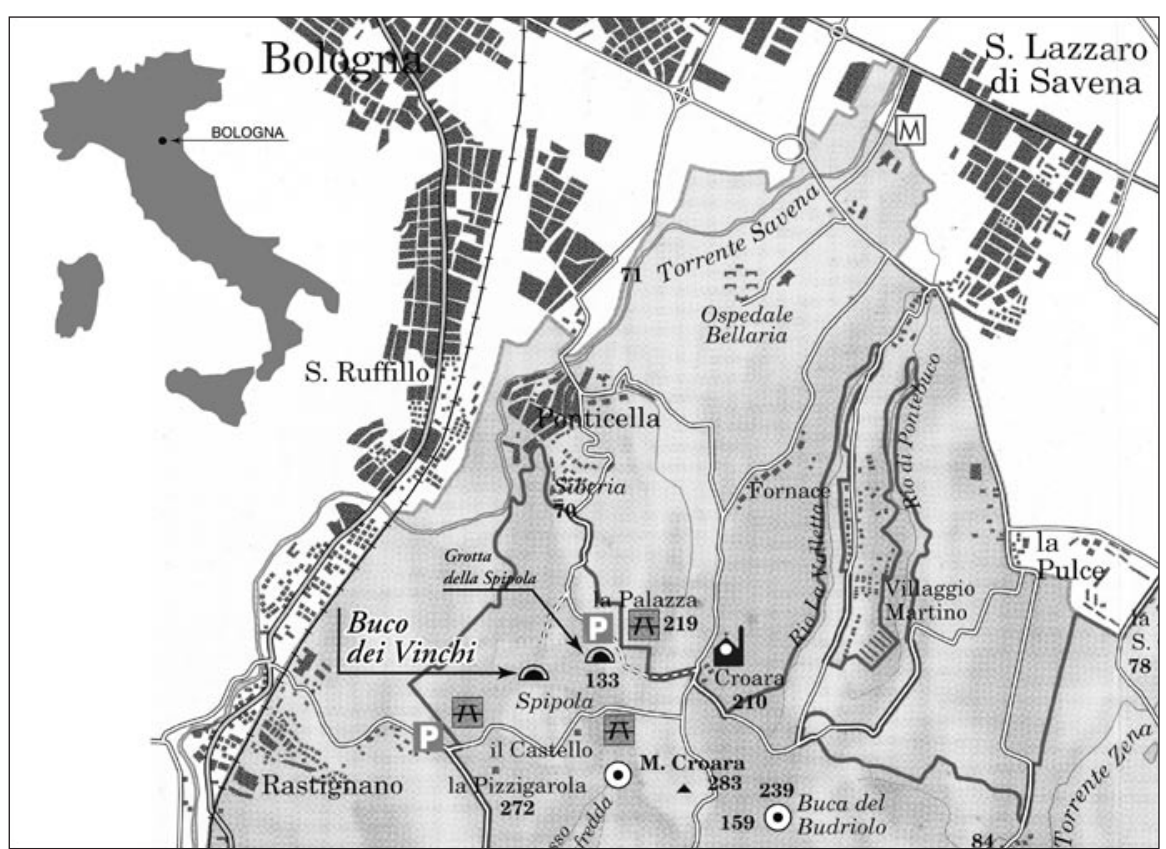

Fig. 1: Location map of the NW area of the "Parco Naturale Regionale dei Gessi Bolognesi e dei Calanchi dell'Abbadessa", where the Buco dei Vinchi inactive swallow hole, the Buca del Budriolo blind valley and the Spipola doline and cave are situated (Fig. 2) (Modified from Antonioli \& Cazzola 1999). 


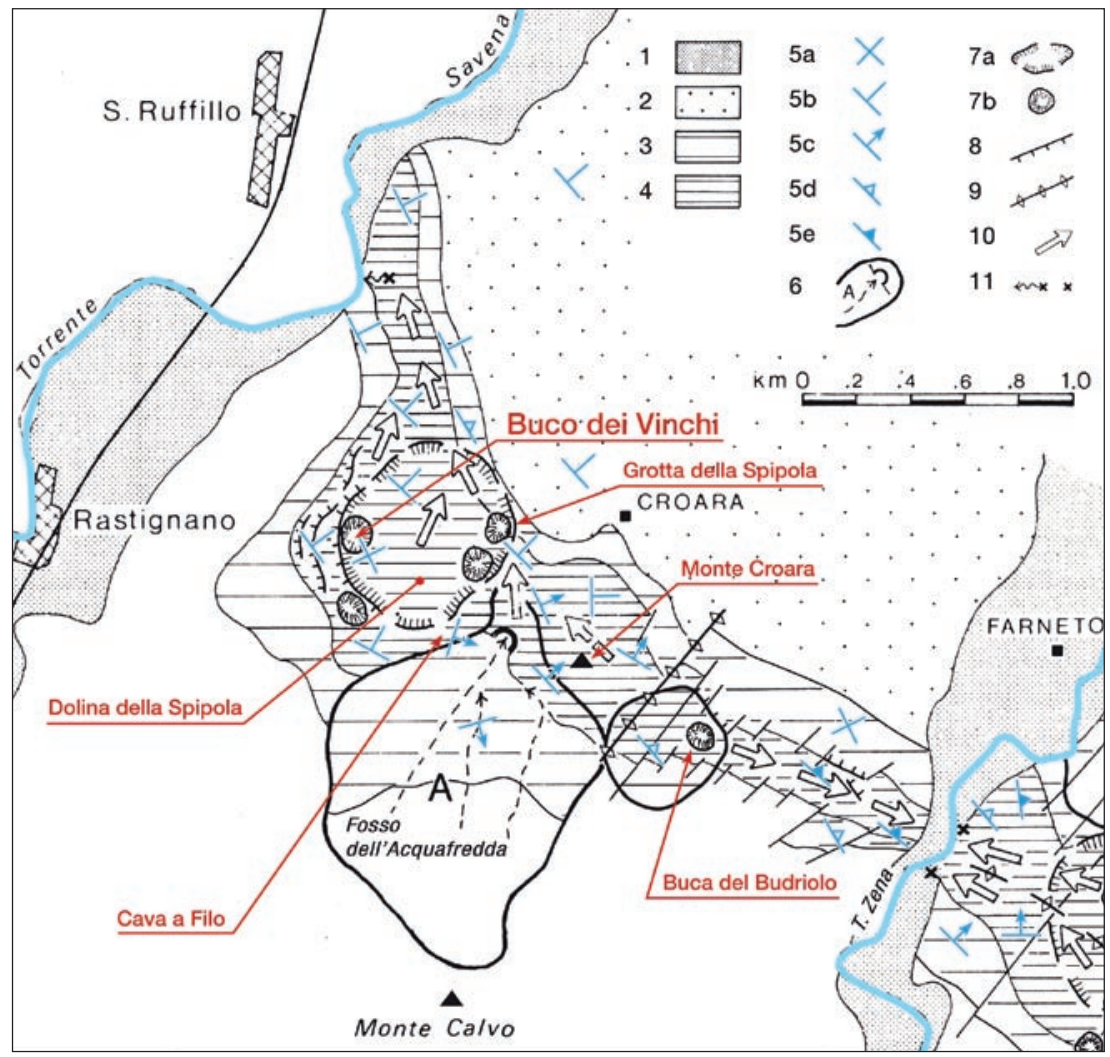

Fig. 2: Geological, geomorphological and hydrogeological map of the Monte Croara gypsum karst sub-area. 1: sediments of the valleys floors, 2: plain sediments, 3: Messinian marls, 4: Messinian selenitic gypsum layers, interbedded with shale layers, $5 a$ : dip of the beds $1^{\circ}-5^{\circ}, 5 b$ : $\operatorname{dip} 6^{\circ}-25^{\circ}, 5$ c: $\operatorname{dip} 26^{\circ}-45^{\circ}$, 5d: dip $46^{\circ}$ $65^{\circ}, 5 e$ : dip $66^{\circ}-85^{\circ}$, 6: blind valleys, $7 a$ \& b: "mother" and "daughter" dolines, 8: main escarps, 9: main ground-water divides, 10: subterranean flow directions, 11: karstic resurgences (Modified from Forti et al. 1985).

Fig. 4: The composite ceiling channel overhanging the "Caverna delle Oreadi" (Source: Photographic archives of the "Gruppo Speleologico BologneseUnione Speleologica Bolognese" [G.S.B. - U.S.B.]).
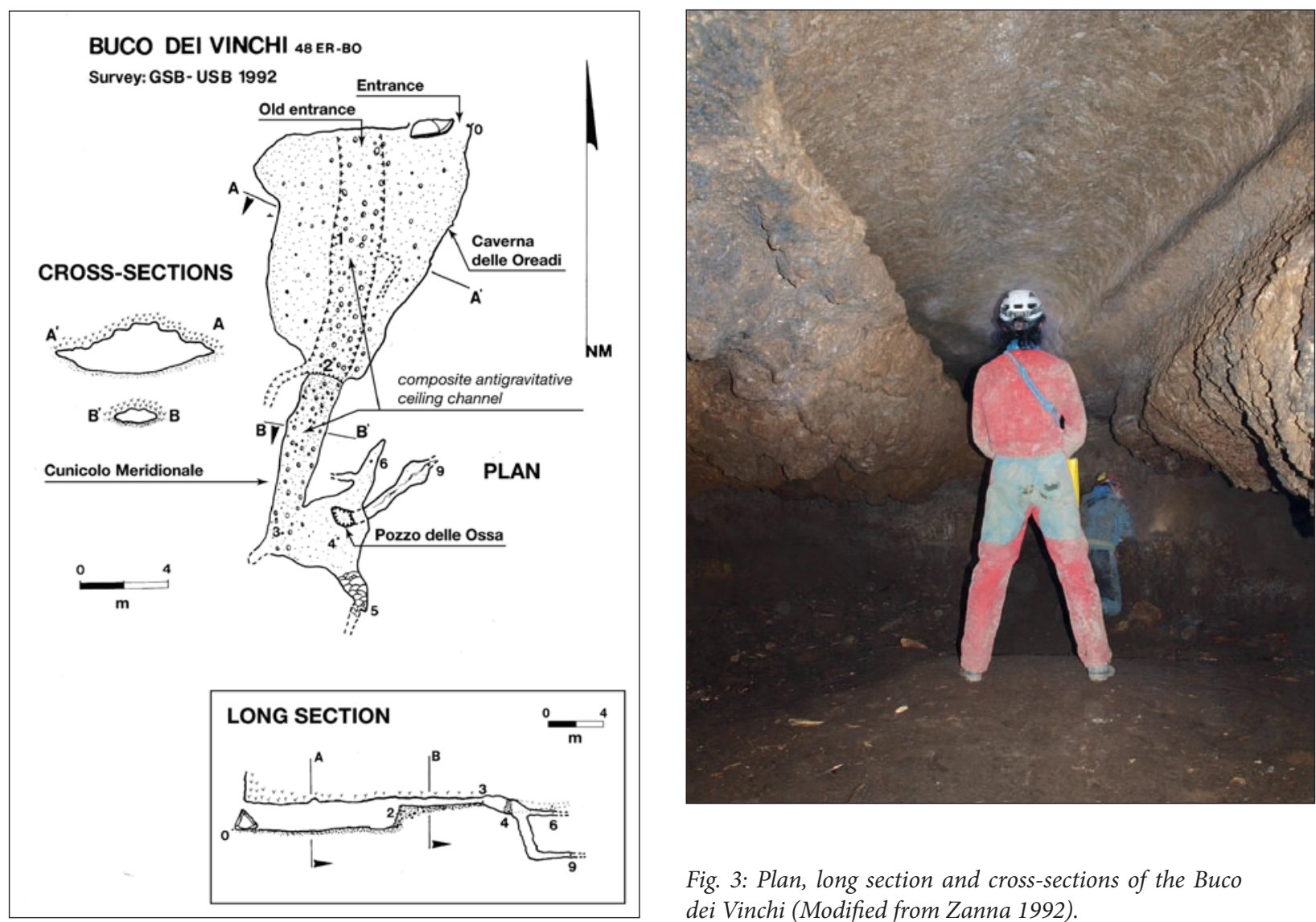

Fig. 3: Plan, long section and cross-sections of the Buco dei Vinchi (Modified from Zanna 1992). 


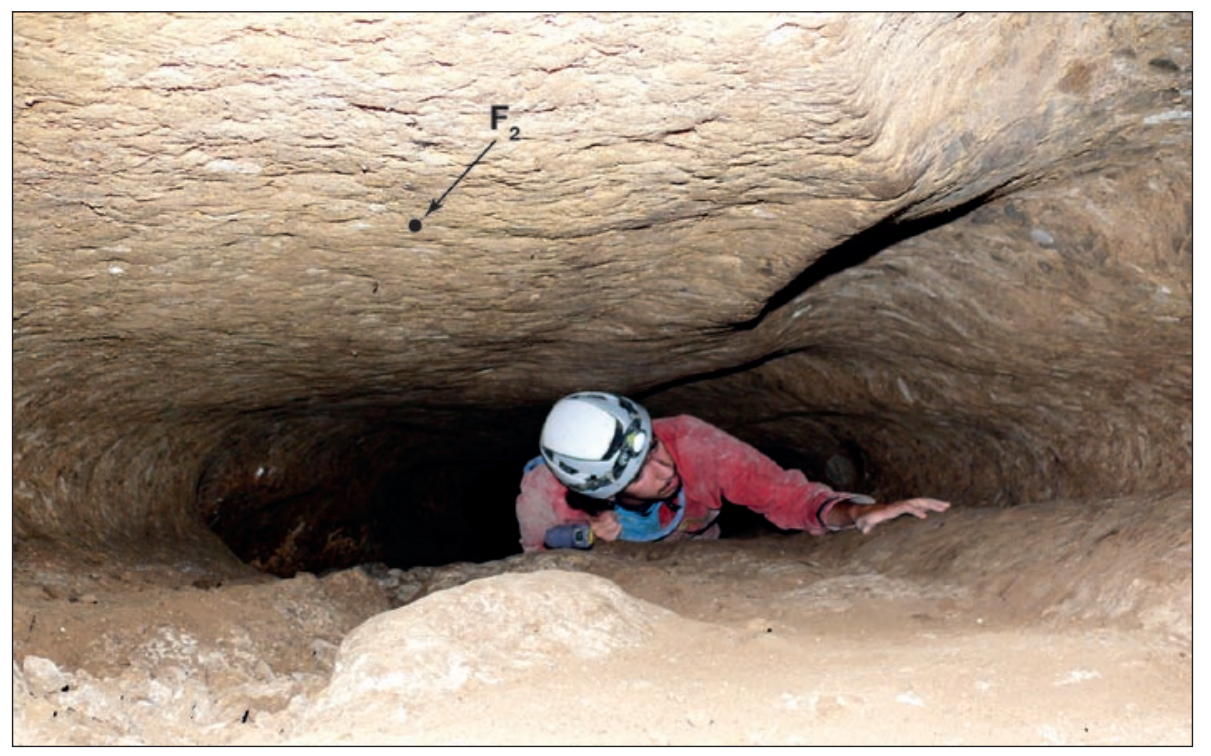

Fig. 5: The "Cunicolo Meridionale" crawl passage, with siltyclayey floor. Point $F_{2}$ on the ceiling is at the same elevation of point F in Fig. 15 (Source: G.S.B. - U.S.B. photographic archives).

Fig. 6: Transition from the "Caverna delle Oreadi" hall to the "Cunicolo Meridionale" crawl passage. Here the filling is cut by a natural subvertical wall about $2 m$ high (Source: G.S.B. - U.S.B. photographic archives).

cave are excavated in selenitic gypsum, Messinian in age. The small Dolina dei Vinchi is situated on the western slope of the large Dolina della Spipola (having a maximum diameter of about $700 \mathrm{~m}$; Fig. 2); its bottom is $60 \mathrm{~m}$ higher than that of the Dolina della Spipola, and $13 \mathrm{~m}$ lower than its nearest ridge. The Dolina della Spipola belongs to the Monte Croara gypsum karst sub-area, which is the portion of the Bologna gypsum karst area delimited on NW and SE by Savena and Zena Torrents, respectively (Demaria 1999, pp. 86-87; Fig. 2).

The Buco dei Vinchi cave begins with a cavern of about $13 \times 9 \mathrm{~m}$, up to $2.35 \mathrm{~m}$ high (Caverna delle Oreadi in Fig. 3); the roof of this cavern is furrowed by a big ceiling channel (Figs. $3 \& 4$ ). The cave continues with a belly crawl (Cunicolo Meridionale in Fig. 3, about $\mathrm{cm}$ 160 wide and $\mathrm{cm} 40$ high), whose floor is detrital: it is the continuation of the ceiling channel (Fig. 6). The crawl ends in a low chamber (Fig. 3: points 3-4), where 5 horizontal small branches choked by mud and the mouth of a pit $3 \mathrm{~m}$ deep (Fig. 3: Pozzo delle Ossa) are visible. Characteristic of this cave is the filling, consisting in grey silty clay with scattered rounded pebbles up to $3 \mathrm{~cm}$ in diameter. At the southern side of the cavern this filling is cut by a subvertical wall, $1.95 \mathrm{~m}$ high (Fig. 3: point 2); the belly crawl begins at the top of this wall (Fig. 6).

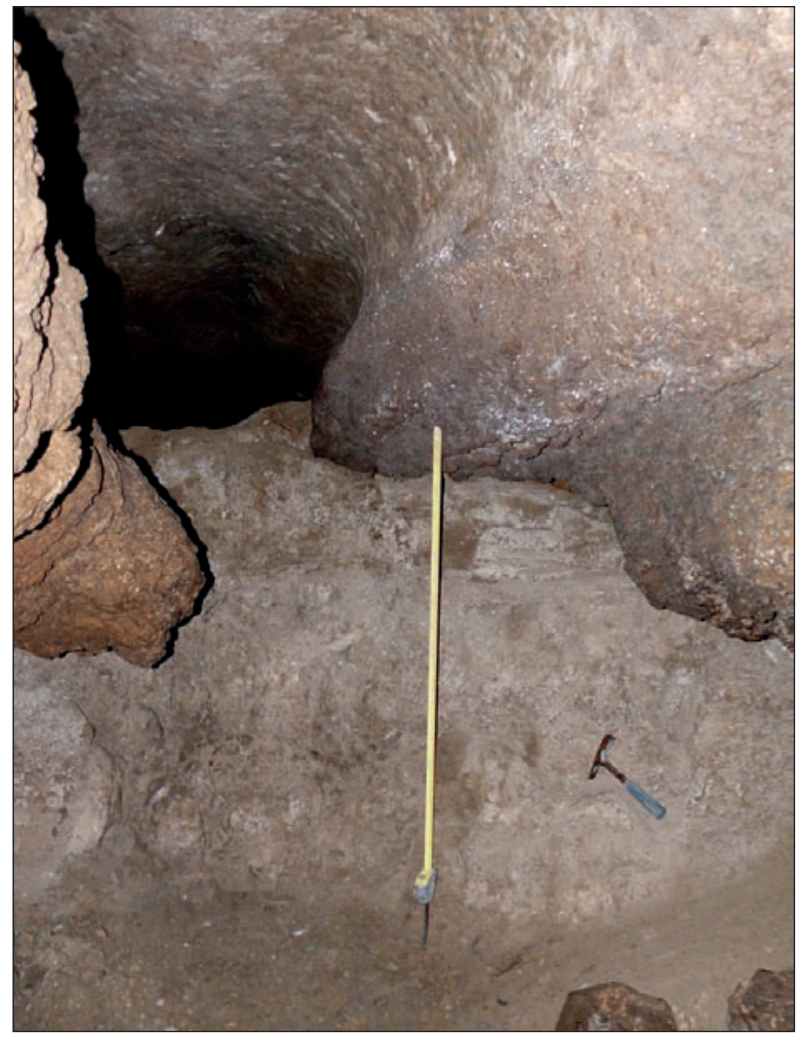

\section{SEDIMENTOLOGICAL AND TECTONIC OUTLINE}

The Buco dei Vinchi is excavated - as said above - in the Messinian selenitic gypsum of the Pedeapennine near Bologna. The stratification of the rocks is not visible inside the Buco dei Vinchi cave or outside close to its entrance, and the structural geology of the area is not known in detail. However, it is clear that the Buco dei Vinchi cave originated at the contact between a subhorizontal shale layer (interbed) and the overlying selenitic 


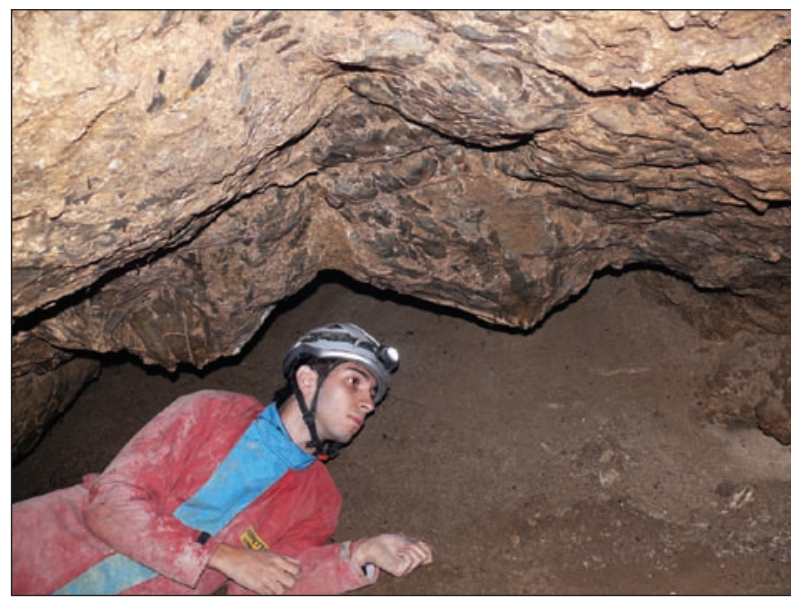

Fig. 7: Two gypsum mammelloni, 'reverse cone'-shaped, with selenite megacrystals converging towards the apex of the cone, in the western side of the "Caverna delle Oreadi" (Source: G.S.B. U.S.B. photographic archives).

gypsum stratum, both Messinian in age (Fig. 15). It was rather difficult to identify the presence of this interbed, because it is hidden by the very similar alluvial filling present in the whole cave. This recognition was made possible only thanks to the detection of some selenitic mamelons (= "mammelloni" [from the Latin word " $m a m$ $m a "=$ breast, mamma + the Italian augmentative suffix “- oni" ] sensu Fantini 1934, pp. 30-31; Vai \& Ricci Lucchi 1977, pp. 226 and Grimandi \& Gentilini 2009, pp. 51, nec Ogniben 1957, pp. 119), hanging from the ceiling of the Caverna delle Oreadi. The mammelloni, named nucleation cones by Dronkert $(1976,1985)$, are reverse cone-

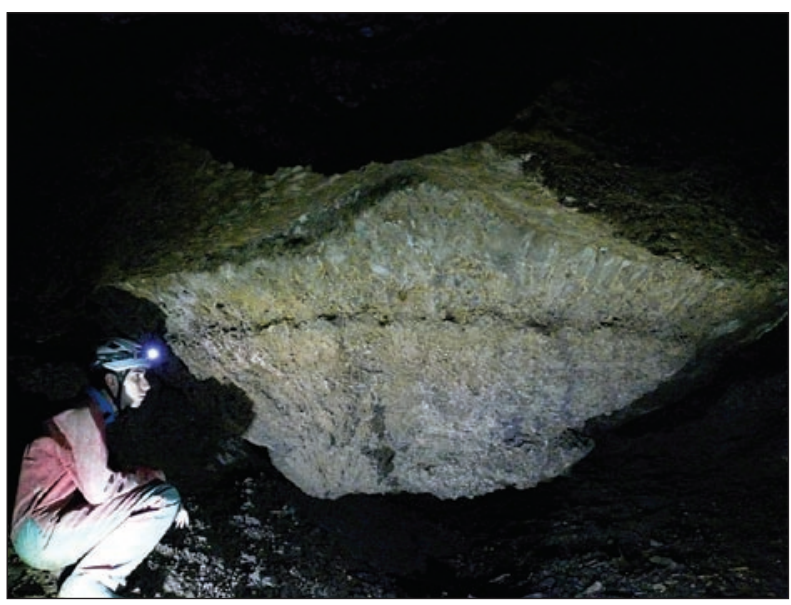

Fig. 8: Huge gypsum mammellone, about $3 \mathrm{~m}$ in diameter, cropping out in the western side of the "Caverna delle Oreadi" (Source: G.S.B. - U.S.B. photographic archives).

shaped clusters of selenite crystals protruding from the bottoms of some gypsum strata always overlying shale layers; so the presence of mammelloni in the ceiling of the cave indicates that this ceiling is the bottom of a gypsum stratum (later partially modified by the physical dissolution and the erosion), which tops a shale layer. Often the diameter of the base of the mammelloni is over one meter, and the height over $50 \mathrm{~cm}$. (Figs. $7 \& 8$ ).

In conclusion, the Buco dei Vinchi cave originated along a subhorizontal bedding plane (guiding bedding plane), separating a gypsum layer with mammelloni (above) from a shale layer (below).

\section{THE ANTIGRAVITATIVE EROSION PROCESS (OR PARAGENESIS)}

The Buco dei Vinchi cave was excavated largely - as it has been mentioned above and as we will see better later - by the antigravitative erosion (or paragenesis). As this process - sketched by Renault in 1958 and explained thoroughly by Pasini in 1967 (Pasini 1967b) and, secondarily, by Renault in 1968 - is infrequently mentioned in literature, it is advisable to remind it in short.

When in a phreatic or epiphreatic or even vadose passage there is sedimentation, the sediments can pile up gradually forming a filling, and can force the stream to flow under pressure between the filling and the cave roof. If the sediments are fine enough - as it happens frequently -, they are generally less erodible (lato sensu: see Howell 1957; Hole 1968; Monkhouse 1970; Goudie, 2004; Pasini 2009) than the karstifiable bedrock (see Hjulström 1939). Therefore the erosion (lato sensu) will work only upwards: so, only the rocky ceiling of the passage will be eroded, whereas the erosion of the rocky floor (which is the floor of the Evakuationsraum, i.e. the totality of the void created by the excavation) is inhibited by the presence of the armoring filling. Consequently the passage will develop only upwards, even for dozens of meters (see Lauritzen \& Lauritsen 1995, pp. 56; Ford 2000, pp. 323; Ford \& Williams 2007, pp. 232) (Figs. 10 \& 11).

Such a process was named by Pasini (1966, pp. 53-55, 1967b, pp. 75) "erosione (lato sensu) antigravitativa" [antigravitative erosion (lato sensu)], because it acts in opposite direction to the force of gravity; it was later termed paragénesis [paragenesis] by Renault (1968) and by all other Authors who mentioned it. Some English-speaking authors (e.g.: Ford 2000; Ford \& Williams 2007; Plan 2010; Farrant \& Smart 2011), while adopting 
the term paragenesis, quoted also the term antigravitative erosion; other authors (e.g.: Lundberg 2005; Šušteršič 2006) recalled the term coined by Pasini in 1966, but mentioned it as antigravitational erosion (see, for details and discussion on this terminology, Pasini 2009, pp. 129-131).

On the other hand, according to Choppy (2008, pp. 176): "paragenetic (Renault 1968)... [is an] etymological inconsistency: this adjective means 'that forms beside, whereas it would mean "what it is excavated upwards", i.e. what results from an ascending excavation." (Translated from French). The same Author added (pp. 177): "syngenetic: term meaning etymologically 'what is formed in the same time', utilized to designate that which is contemporary with the deposition of the sedimentary layers; the usage of the term 'syngenetic conduit' as synonimous of phreatic tube (Renault 1968) is an inconsistency." (Translated from French). Quite independently, in the above mentioned paper, dedicated essentially to the close etymological examination of some speleological terms, Pasini (2009, pp. 137) wrote: "In conclusion, I believe that the terms paragenesis and antigravitational erosion should be replaced by the students of speleomorphology and speleogenesis with the term antigravitative erosion - for reasons of priority, etymology and physical meaning -, and that the attributes paragenetic and antigravitational should be replaced with the attribute antigravitative. I think that also the terms syngenesis and syngenetic - in the meaning proposed by Renault (1968) - should be forsaken".

In the above mentioned paper (Pasini 2009) it is emphasized the importance of the correct use of terminology, in speleology as well as in all other sciences, by quoting a sentence of Sigmund Freud; here I stress the point by quoting an aphorism of Galileo Galilei (1612): "I nomi e gl'attributi si devono accomodare allessenza delle cose, e non l'essenza ai nomi; perché prima furon le cose, e poi $i$ nomi." [The names and the attributes must fit the essence of the things, and not the essence fit the names; because the things were first, and then the names].

Ford (2006, pp. 7-8) wrote: "North American workers have been slow to recognize the significance of two secondary speleogenetic processes. The first is condensation corrosion ... The second is paragenesis ... This can often result in the formation of entirely new bypass or overflow passages, including local mazes. I have seen many instances of this in the Appalachian caves, where the limestones are frequently overlain or flanked by shales and sandstones." Farrant too (2004, pp. 571) wrote “...vadose and paragenetic passages have very different geomorphic and paleoclimatic implications, yet the true extent and significance of paragenesis and alluviation in speleogenesis and development is probably underestimated."

\section{THE “BANQUETTES” (FILLING WALL LEDGES)}

Before going on, I have to recall two similar definitions of "banquette" (filling wall lege, Fig. 12), because these speleoforms are well represented and very significant in the Buco dei Vinchi cave. According to Renault (1968, pp. 568) "The (filling wall) ledges are oblong bulges in the walls, corresponding to the old top of a filling, subsequently removed. (Translation from French). Choppy (2008, pp. 134) added: "If the top of the sediments is stable, the widening of the walls through the action of excavation will not occur except above the sediments: the evidence of the filling is, in this case, a filling wall ledge..". (Translation from French).

I agree with this interpretation given by Renault and by Choppy of the banquettes.

Now I will proceed to the genetical interpretation of the Buco dei Vinchi cave, which is rather complex.

\section{SPELEOGENESIS OF THE “CAVERNA DELLE OREADI”}

\section{PHREATIC PHASE A}

The vault of the Caverna delle Oreadi - excluding, for the moment, its big ceiling channel - coincides with the bottom of a subhorizontal gypsum layer (see chap. "Sedimentological and tectonic outline"), partially modified by the physical dissolution and the mechanical erosion. Immediately below this stratum there is surely an inter- bed of shale, not visible inside the cave because hidden by the filling. And it is just from the bedding plane between this shale layer (below) and the gypsum layer (above) that the cave originated: in fact in the entire cavern no other bedding planes or fractures are visible. In this connection I recall what Ford \& Williams (2007, pp. 31) wrote: "Groundwater penetration to initiate karst is often easier 

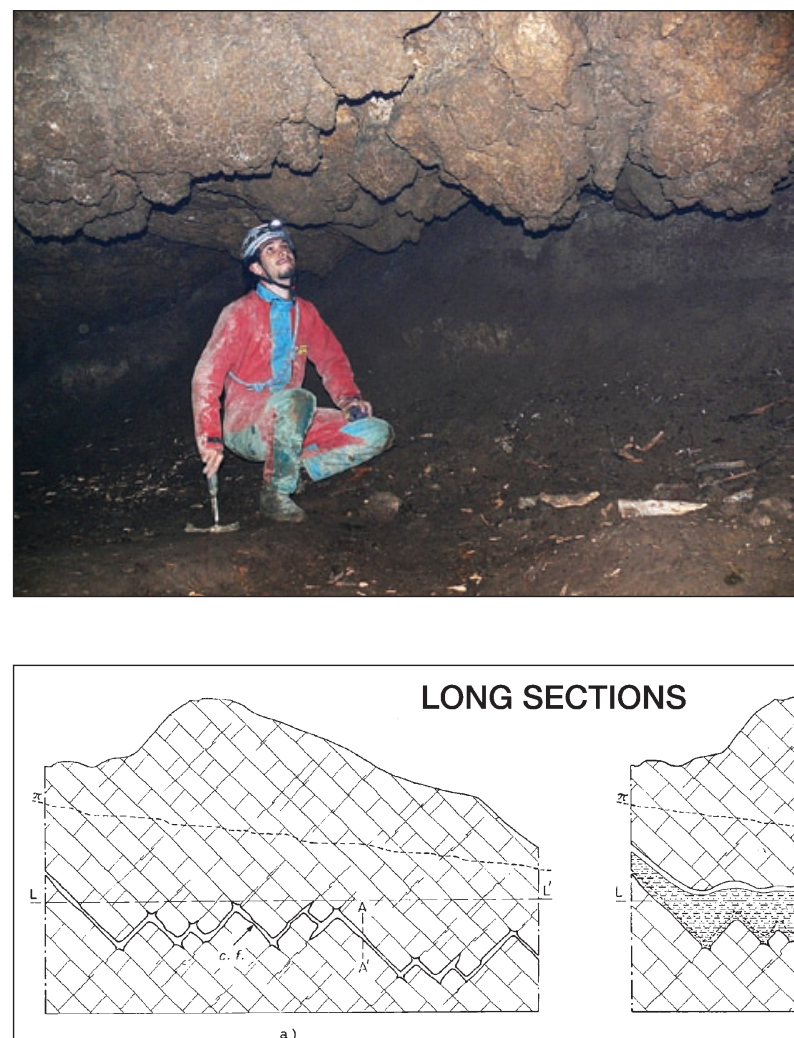

a)
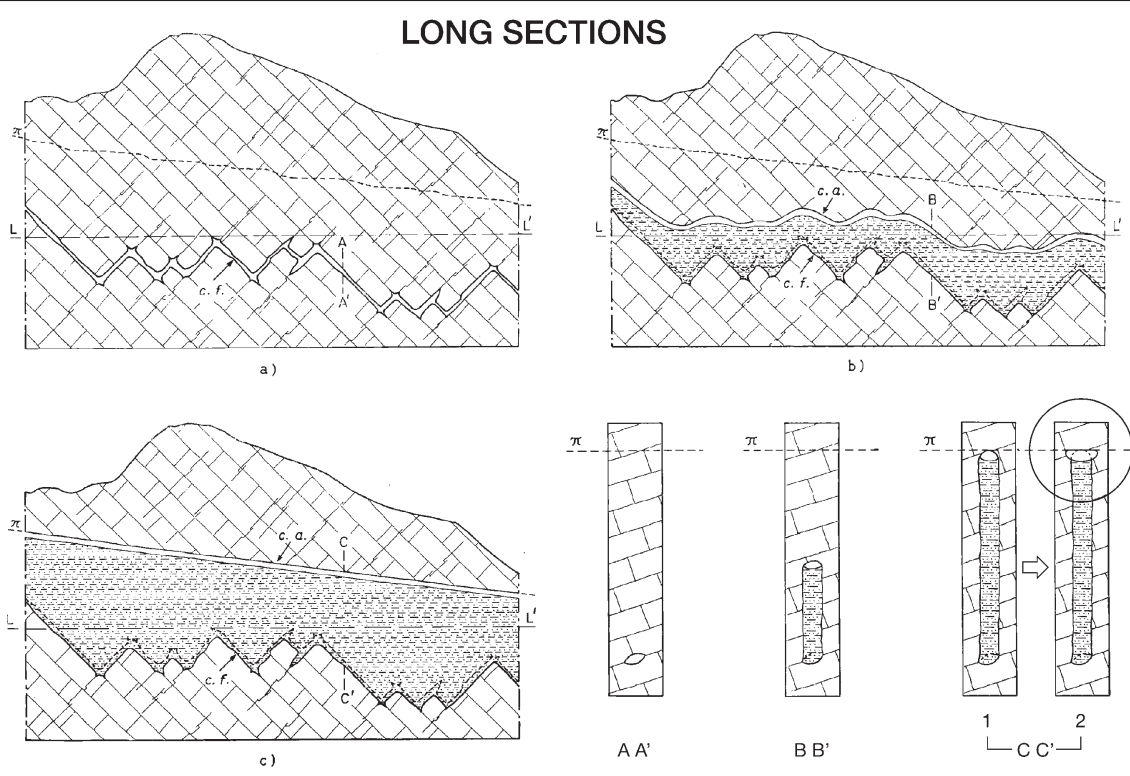

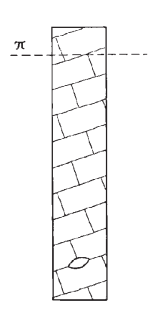

A A'

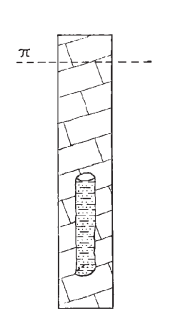

B B

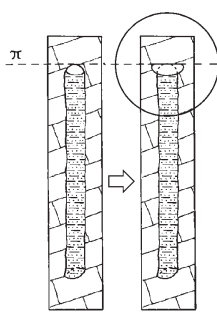

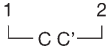

CROSS-SECTIONS
G. Pasini 2010

Fig. 10: Evolutive scheme of an antigravitative cave in fractured karstifiable rocks, with strata dipping $\sim 45^{\circ}$, during a long stillstand of the piezometric surface. The alternate rows of broken lines and dots represent clayey-silty sediments.

10 a represents, in long section, a stretch of a normal system of phreatic tubes, developed along bedding planes and joint planes.

$10 \mathrm{~b}$ \& $10 \mathrm{c}$ represent the evolution of such galleries in an intermediate phase and at the end of the antigravitative erosion process, respectively: the phreatic tubes are compelled to develop upwards by antigravitative erosion because of the ever-growing sedimentary filling, which forces the underground canalized stream to erode only the ceilings and upper walls of the conduits and to flow at ever higher levels, until the piezometric surface is reached. $\pi=$ trace of the piezometric surface; $L$ $L^{\prime}=$ local base level; $c . f .=$ system of phreatic tubes; $c . a .=$ system of antigravitative pseudo-'phreatic tubes' (Pasini1975, pp. 297); $A A^{\prime}, B B^{\prime}$ and $C C^{\prime}=$ cross-sections of a segment of the cave during its evolution (the cross-sections are twice the size of the long sections). If the piezometric surface remains long enough at level $\pi$, the antigravitative pseudo- 'phreatic tube' of Fig. 10c and of cross section CC'.1 - with arched vault - turns into a post-antigravitative (or post-paragenetic) conduit with flat subhorizontal ceiling (cross section CC'.2), as evidenced by the circle: see Chapter "Antigravitative erosion + post-antigravitative erosion phase C" (Modified from Pasini 1967b). ("initiation phase" of Bosák 2003, pp. 8; White 2007, pp. 48). This happened, at the beginning, owing to the "normal" (i.e. non-antigravitative) erosion (lato sensu : see Pasini 2009, pp. 129) of both the shale and the selenitic gypsum. So water flowed initially forming several phreatic protoconduits (sensu White 2007, pp. 48). Unfortunately no example of protoconduit survives today in the Buco dei Vinchi cave. However it is likely that the largest protoconduits, having diameters of 5-15 mm (Bosák 2003, pp. 8; White 2007, pp. 48; Bosák 2008, pp. 30), had subelliptical or subcircular crosssections (Fig. 13a \& b; see also Ford \& Williams 1989, pp. 294, and 2007, pp. 249).

The first phreatic phase lasted very little, because the protoconduits - given the big quantity of pelites (coming mainly from the shale interbed) that water transported - turned very soon into small antigravitative conduits, 'reverse U'-shaped and sometimes bulb-shaped in crosssections (Fig. 13). This marks the beginning of the antigravitative erosion period of the cave. 


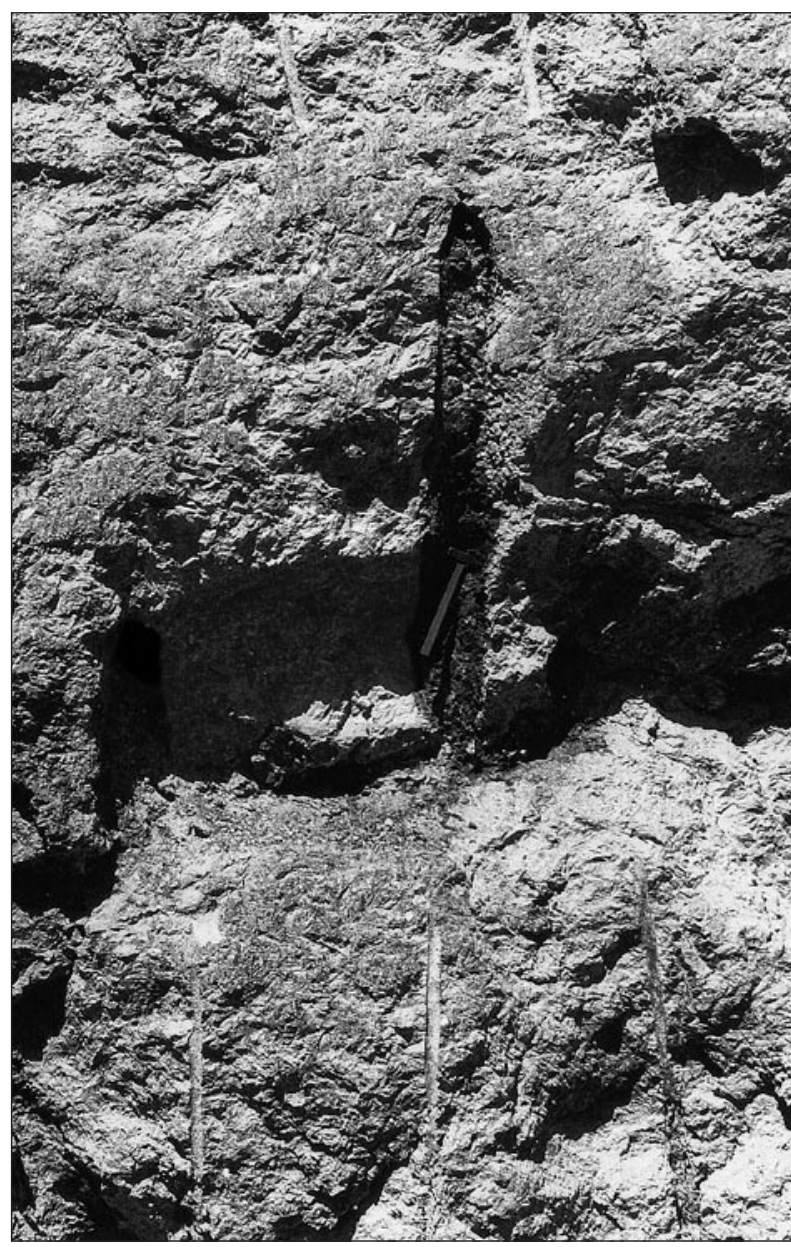

Fig. 11: Very rare example of a complete and perfect antigravitative groove, thoroughly filled with alluvial clayey silt including rare rounded pebbles, cut in the Messinian selenitic gypsum of the "Fiorini Quarry" (near "Farneto", Bologna, Italy; see Fig. 2). At first a small phreatic conduit originated in correspondence of a subhorizontal joint plane, clearly visible in the picture. Afterwards the water, circulating under pressure in the conduit, was forced by the alluvial deposits piled up on its floor to flow at ever higher levels, excavating only the ceiling and the upper walls of the conduit. It should be noted that there are neither bedding planes nor fractures near the top of the groove. It should be noted also that the cross section of this antigravitative groove is identical to the cross section CC'.1 of Fig. 10. At the left of the main groove a smaller groove, only partially filled with sediments, is visible. The bigger antigravitative groove is $150 \mathrm{~cm}$ high and 15$20 \mathrm{~cm}$ wide, the smaller is $65 \mathrm{~cm}$ high (From Pasini 1967a).

\section{ANTIGRAVITATIVE EROSION PHASE B}

Many small antigravitative ceiling channels are visible today in the roof of the Caverna delle Oreadi (Figs. 16-19). Water rivulets ran through these channels when they were active; the channels vary in size: the smallest are $\sim 10 \mathrm{~cm}$ in width and $\sim 15 \mathrm{~cm}$ in height; the biggest are $\sim 20 \mathrm{~cm}$ in

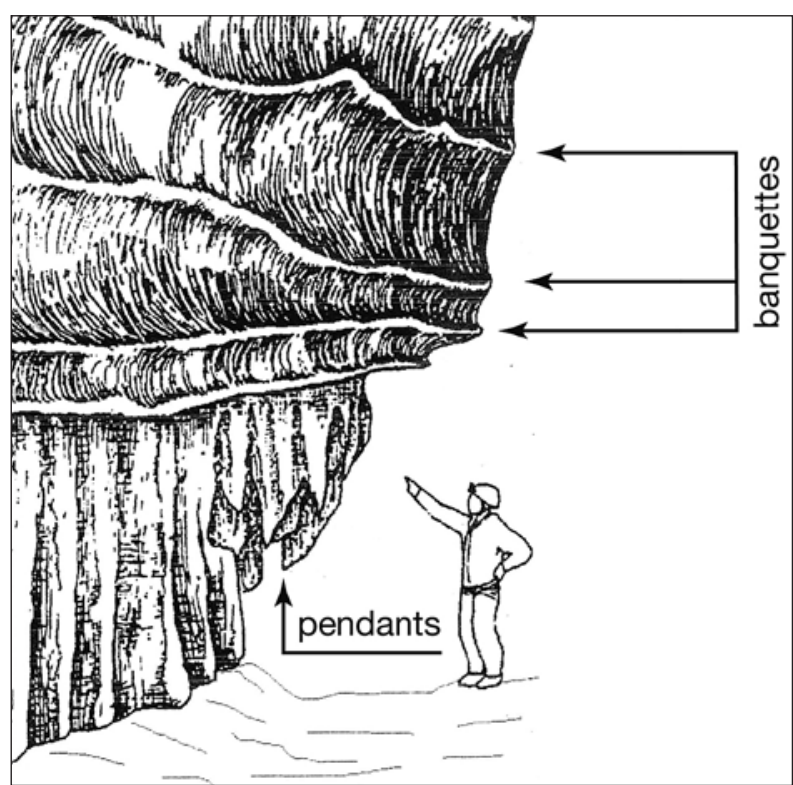

Fig. 12: Banquettes in the Cueva Cañuela cave (Spain). For explanations see text (Modified from Bigot \& Morverand 1994).

width and $\sim 30 \mathrm{~cm}$ in height. These small antigravitative ceiling channels were originally small antigravitative conduits (Figs. 13c \& d).

The simplest hypothesis might be to admit that the protoconduits of the Buco dei Vinchi were firstly transformed into phreatic tubes with a diameter of about $10-20 \mathrm{~cm}$, and that these tubes turned later into antigravitative conduits of the same width. But I don't think that it is what happened, because the sizeable sedimentation should not have allowed the protoconduits to enlarge in normal phreatic tubes. I think instead that, in the Buco dei Vinchi, the protoconduits having maximum diameters of $10-15 \mathrm{~mm}$ transformed into small antigravitative conduits $10-20 \mathrm{~cm}$ wide in a very short time (Fig. 13). In cross-section the connections between protoconduits and small antigravitative conduits should have been ' $\mathrm{V}$ 'shaped (Fig. 13c \& d). To this regard, recall the "bulb cross-sections" mentioned by Bretz (1942, pp. 707-708) for the "bedding plane anastomoses" found in limestone caves of Ohio and Kentucky, and the analogous crosssections illustrated by Pasini (1967a, Figs. 16-18 \& 22a) for quite similar speleoforms observed in gypsum caves of the Bologna karst area.

The small antigravitative conduits, deriving from the antigravitative evolution of the phreatic protoconduits, had walls and vault carved in gypsum, and pelitic floor. Later on the pelites forming the floor were removed by vadose erosion (which often reduced or eliminated also the two lower, symmetrical protrusions of the walls; Fig. 16); and consequently the original small antigravitative conduits turned into small antigravitative ceiling 


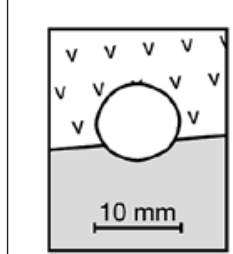

a)

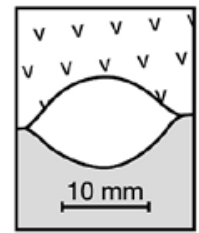

b)

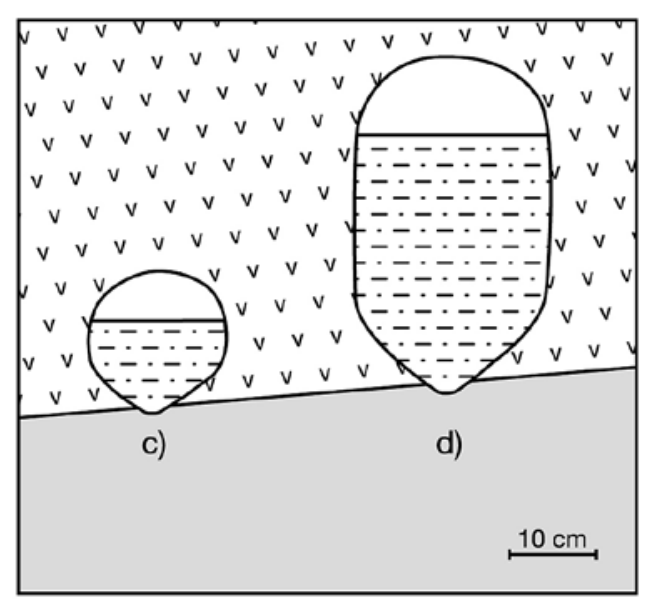

G. Pasini, 2010
Fig. 13: Hypothesis on the formation of the small antigravitative conduits. a) well developed phreatic protoconduit with subcircular cross section; b) well developed phreatic protoconduit with subelliptical cross section; c) small antigravitative conduit with bulb-shaped cross section, developed from one of the phreatic protoconduits shown in $13 a$ \& $13 b$; d) small antigravitative conduit with 'reverse $U$ '-shaped cross section, developed from one of the phreatic protoconduits shown in $13 a$ \& $13 b$. channels ('reverse U'-shaped or bulb-shaped in cross section), overhanging the Caverna delle Oreadi.

The network formed by the small antigravitative ceiling channels (Figs. 21 \& 22) is very irregular and complicated (although the course of some of them is conditioned by the mammelloni: Fig. 20); it is quite different from the networks formed by the bedding plane anastomoses illustrated by Bretz (1942, pp. 706-708; Figs. 14-16), by Pasini (1967a, Pl. X, Fig. 1) and by Calaforra (1998, Fig. II. 35).

The small antigravitative ceiling channels can highlight mammelloni (frequent mainly in the western side of the cavern: Fig. 20) and isolate pendants (frequent mainly in the eastern side of the cavern: Fig. 9); several pendants derive undoubtedly from the antigravitative erosion of mammelloni (Fig. 22).
The small antigravitative conduits - with their running water rivulets - converged and merged together in successive stages to form ever-larger conduits, until - at a certain point - most of them flowed into a unique, much wider antigravitative conduit. This conduit, located approximately along the major axis of the Caverna delle Oreadi, had an arched or semicircular vault (Fig. 15a). From then on this last antigravitative conduit drained all the water of the Buco dei Vinchi cave, that at the time was gathered in a unique stream under pressure.

Similar phenomena were observed by Calaforra (1998, pp. 156-157) in the Sorbas karst area (Spain), but they were differently interpreted.

\section{SPELEOGENESIS OF THE COMPOSITE CEILING CHANNEL}

The wide ceiling channel located roughly along the main axis of the Caverna delle Oreadi (Fig. 3) was originally a composite conduit, in that it derived from the superposition and partial coalescence of four different component conduits (Fig. 15e: $\alpha, \beta, \gamma \& \delta$ ). At the end of its formation this composite conduit was almost completely choked by pelitic sediments (filling). Later on part of the filling was removed by vadose erosion (see below), so that the original composite conduit turned into a composite ceiling channel, ovehanging the Caverna delle Oreadi (Fig. 14; see also "forme complesse" [complex forms] in Pasini 1967a, pp. 55).
The composite ceiling channel constitutes the upper part of the cave, about from the altitude of point $A_{1}$ to that of point $\mathrm{H}$ (Fig. 15e). Its morphology can be explained by admitting that the dissolution-erosion phases by which it was originated took place during a period of rise of the piezometric surface, interrupted by some stillstands.

For the sake of brevity, the four superimposed components of the composite ceiling channel noticeable in the cave will be named $\alpha, \beta, \gamma$ and $\delta$ (Fig. 15), as mentioned above. 
At a certain point - it is useful to repeat - the stream under pressure, continuing to pile up sediments, began to carve by antigravitative erosion a single reverse channel in correspondence of the top of the cavern's vault. We can imagine - in a schematic way - that the succession of the events which lead to the formation of this reverse channel was the following.

\section{ANTIGRAVITATIVE EROSION PHASE B (CONTINUATION)}

At a certain moment of the history of the cave the top of the filling reached the altitude of point $\mathrm{A}_{1}$ (Fig. 15a), while the local piezometric level was at the altitude of point $\mathrm{A}_{2}$. In these circumstances the stream, working in antigravitative erosion conditions, carved the big reverse channel $\alpha$, with arched or semicircular vault (Fig. 15a). Some time later the roof of $\alpha$ reached point $\mathrm{A}_{4}$ and the filling point $\mathrm{A}_{3}$ (Fig. 15b).

This phase is the prosecution of phase $\mathrm{B}$, described above for the Caverna delle Oreadi.

\section{ANTIGRAVITATIVE EROSION + POST- \\ ANTIGRAVITATIVE EROSION PHASE C}

Of component $\beta$ of the composite conduit it remains today only the western wall, consisting of the horizontal arched groove located between points $\mathrm{A}_{2}$ and $\mathrm{D}_{2}$ (Fig. 14). The western wall of $\beta$ - about $40 \mathrm{~cm}$ high - is morphologically very similar to the walls of $\gamma$ (Fig. 14 ); so it is very likely that also component $\beta$ of the composite conduit had a flat subhorizontal ceiling, as component $\gamma$ (see below).

When the rising piezometric surface reached level $\mathrm{D}_{2}$ the apex of the vault of the underlying antigravita- tive conduit was at level L (Fig. 15c). Afterwards a long stillstand occurred: for a rather long time the piezometric surface remained motionless at level $\mathrm{D}_{2}$ (apart from several probable minor fluctuations: see below). While the piezometric surface stood at level $\mathrm{D}_{2}$, the underlying conduit continued to develop upwards by antigravitative erosion. At a certain moment the apex of the vault of this conduit reached point $\mathrm{D}_{2}$, and so it became tangent to the stationary piezometric surface.

Soon after the water at the top of the antigravitative conduit was in free flow conditions, and its surface coincided with the piezometric surface.

After the apex of the conduit's vault reached the piezometric surface, this surface continued to stay at level $\mathrm{D}_{2}$ for a rather long time. Obviously in these conditions the conduit could not develop upwards any more, but it could only widen. Consequently the roof of the conduit was cut, bevelled, flattened by the free-surface of the water, which transformed the arched vault in a flat and subhorizontal ceiling.

Component $\beta$ formed in this way, and so this stretch of the cave turned temporarily from antigravitative conduit into post-antigravitative conduit (see Pasini, in preparation); at the end of this phase - it is useful to repeat - the free surface of the stream, coinciding with the piezometric surface, was tangent to the flat subhorizontal ceiling of component $\beta$ (Fig. 15c).

During this entire phase the bottom of the stream (= the top of the filling) should have been at level C (Fig. 15c): only in this case, in fact, the arched shape of the wall of component $\beta$ seems explainable. The long stillstand of the top of the filling at level $\mathrm{C}$

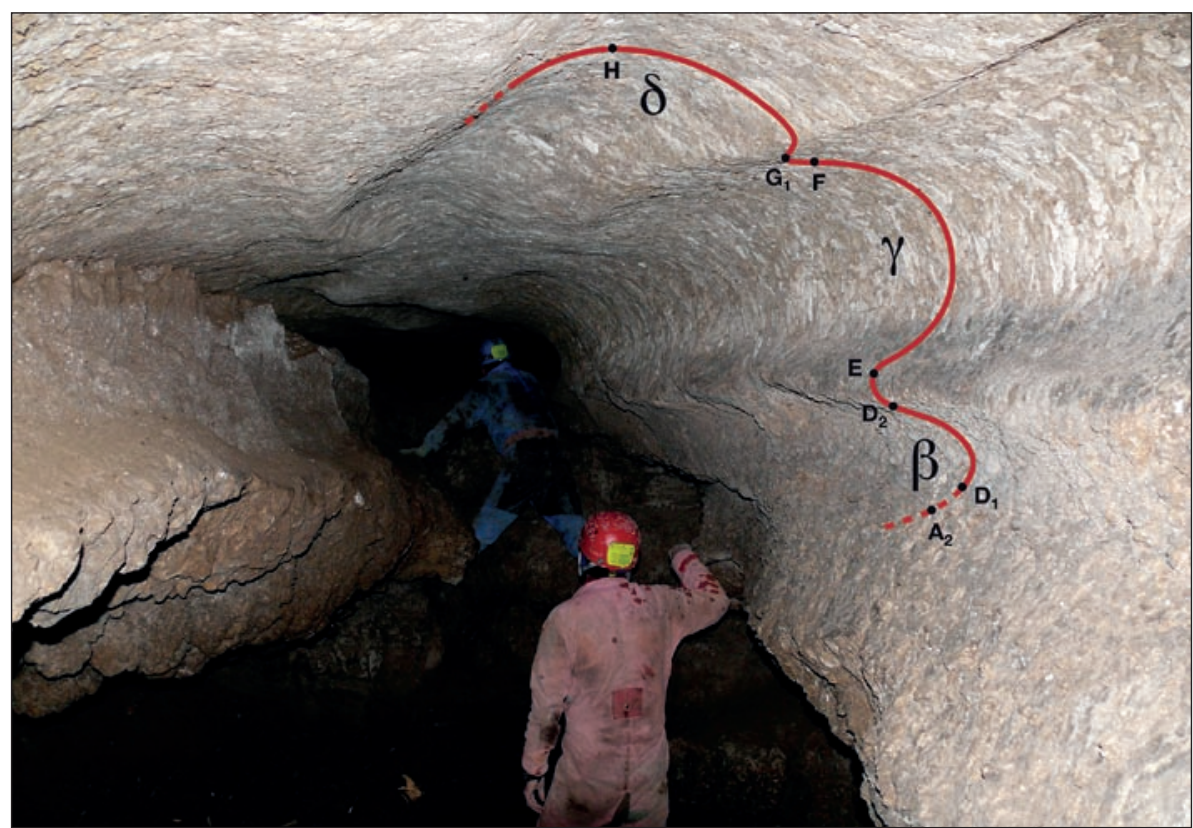

Fig. 14: The composite ceiling channel of the Buco dei Vinchi swallow hole: components $\beta$, $\gamma$ and $\delta$ are evidenced. For the meaning of the other letters see text (Source: G.S.B. - U.S.B. photographic archives, modified). 


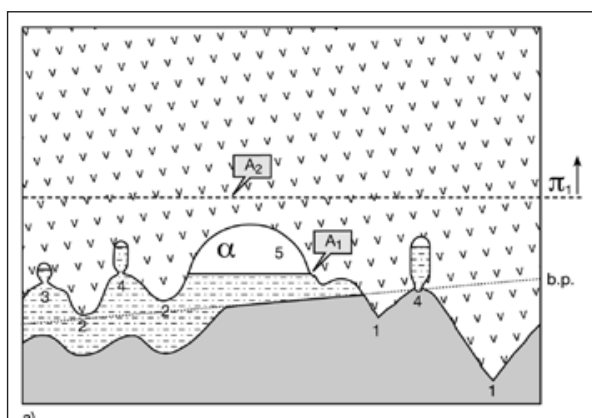

a)

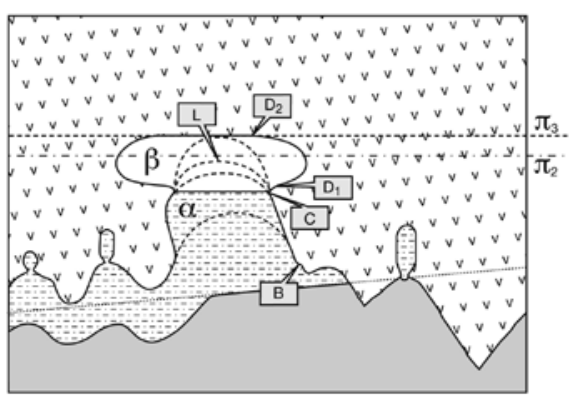

c)

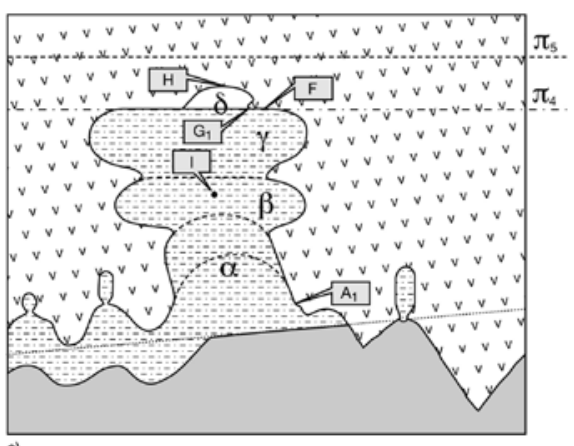

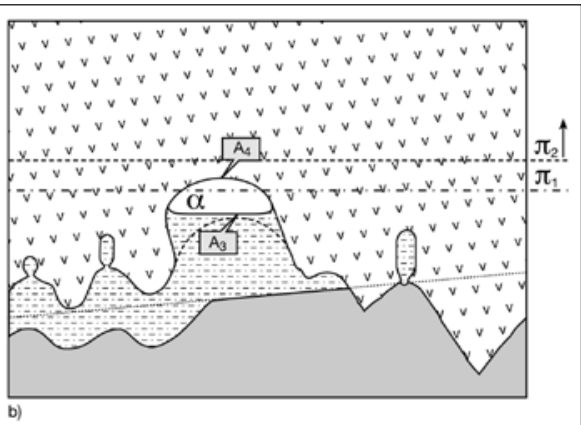
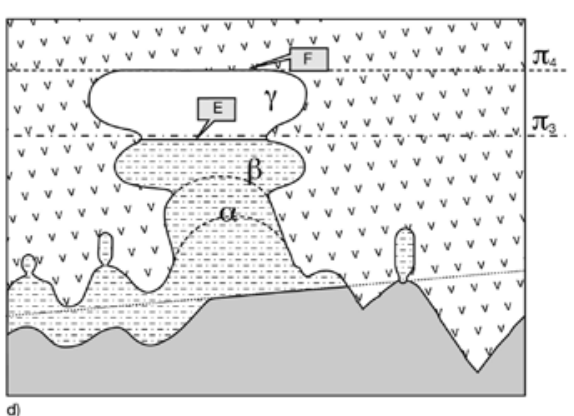

d)

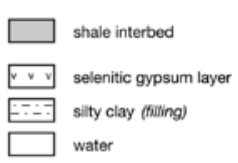

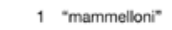

2 rock pendants

rock pendants

aulb-shaped small

4 reverse ' $U$ '-shaped small

reverse ' 'U'-shaped smaa
antigravitative conduits

5 main antigravitative condul

b.p. trace of the bedding plane

$\pi_{1}-\pi_{5}$ local levels

of the piezometric surface

$A_{1}-L$ letters quoted in the text

G. Pasini, 2010

Fig. 15: Evolution of the composite conduit of the Buco dei Vinchi. a) Forming of the large component antigravitative conduit $\alpha$, with arched vault: the small antigravitative conduits converged and merged together in successive stages to form everbigger conduits, until - at a certain point - many of them flowed into a unique, much wider antigravitative conduit $(\alpha)$. b) The piezometric surface raised from $\pi_{1}$ to $\pi_{2}:$ upwards evolution of the component antigravitative conduit $\alpha$, with arched vault. c) The piezometric surface raised from $\pi_{2}$ to $\pi_{3}$, and then stood a long time at level $\pi_{3}$ : transformation of the conduit with arched vault into the bigger post-antigravitative conduit $\beta$, with flat subhorizontal ceiling. d) Further raising of the piezometric surface till to level $\pi_{4}$, and then long stillstand of this surface at level $\pi_{4}$ : forming of post-antigravitative conduit $\gamma$, with flat subhorizontal ceiling. e) The piezometric surface raised from level $\pi_{4}$ to level $\pi_{5}$, located at an indeterminable altitude above point $H$ : forming of the component antigravitative conduit $\delta$, with arched vault. Further explanation is in the text. allowed the erosion of the walls only above this level, giving origin to a "banquette" of a sort in both sides of the conduit.

\section{ANTIGRAVITATIVE EROSION + POST- ANTIGRAVITATIVE EROSION PHASE D}

Afterwards the piezometric level rose as far as the altitude of point F (Figs. $14 \& 15 \mathrm{~d}$ ), and the top of the filling rose to the elevation of point $\mathrm{E}$. The process illustrated in the preceding section repeated itself step by step, and component $\gamma$ formed, together with a second couple of "banquettes" at level E. In particular, also in this case the piezometric surface had a long stillstand (at level F), so that also this stretch of the cave turned, temporarily, from antigravitative gallery into post-antigravitative conduit. Component $\gamma$ of the composite antigravitative conduit, having flat subhorizontal roof and arched walls, is about $1.5 \mathrm{~m}$ wide and $60 \mathrm{~cm}$ high; its size - as the sizes of the other components - depends on the stream discharge and on the time of permanence of the piezometric surface at the same level.
The ceiling of $\gamma$ is flat and subhorizontal because it was flattened by the free surface of the stream - coinciding with the piezometric surface of the time which remained for a rather long while tangent to this ceiling. The difference in elevation between point $\mathrm{D}_{2}$ $\left(1^{\text {st }}\right.$ stillstand) and point $\mathrm{F}$ ( $2^{\text {nd }}$ stillstand $)$ is of $0.5 \mathrm{~m}$ ca.

\section{ANTIGRAVITATIVE EROSION PHASE E}

After the long stillstand at height $\mathrm{F}$ the piezometric level moved again upwards, rising from level $\mathrm{F}$ to an indeterminable altitude above that of point $\mathrm{H}$ (Fig. 15e). So component $\gamma$ of the composite conduit was completely filled with clayey-silty sediments, which forced the stream to carve from the bottom upwards - by antigravitative erosion - the highest stretch of the conduit, i.e. component $\delta$ (Fig. 15e). Component $\delta$, with arched vault culminating in point $\mathrm{H}$, is much smaller than the two underlying components, being about $0.5 \mathrm{~m}$ wide and $15 \mathrm{~cm}$ high: this can be due either to a decrease of the stream discharge at the time when $\delta$ was excavated and/or to a short per- 
manence of the piezometric surface over the ceiling of component $\delta$.

The vault of component $\delta$ is arched - and not flat and subhorizontal as the one of $\gamma$ - because the vault of component $\gamma$, as said above, was for a long time tangent to the piezometric surface and moulded by the free surface of the stream, whereas the vault of component $\delta$

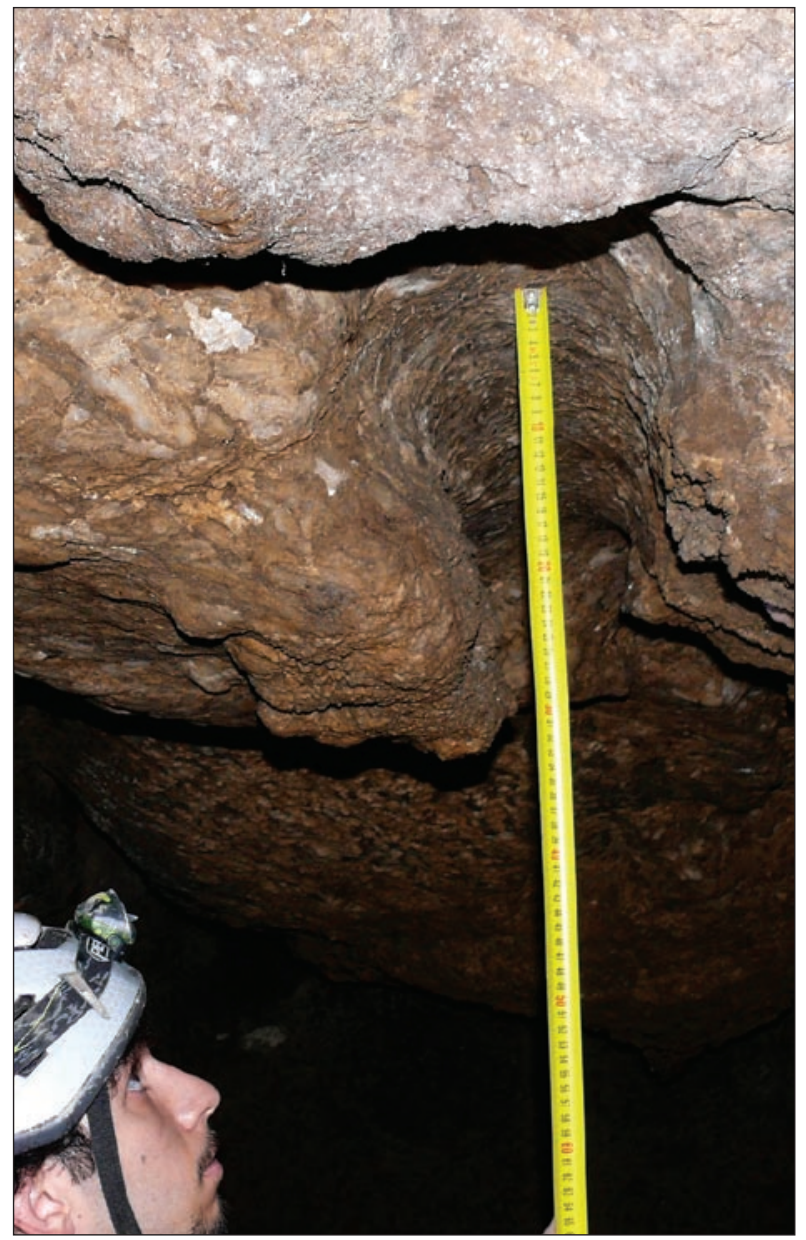

Fig. 16: Small antigravitative ceiling channel with bulb-shaped cross section in the Caverna delle Oreadi (Source: G.S.B. - U.S.B. photographic archives).

was always located below the piezometric surface. Consequently component $\delta$ was excavated under pressure, like a phreatic tube (of which, in fact, it reminds us the morphology): the only difference is that component $\delta$ was excavated by antigravitative erosion, and not by phreatic erosion.

Local remains of "banquettes" can be observed at the level of point $\mathrm{G}_{1}$ (Figs. 14 \& 15e).

At the end of the antigravitative erosion phase $E$ the Caverna delle Oreadi and the composite conduit $(\alpha+\beta$ $+\gamma+\delta$, which will partially turn into a composite ceiling channel: Fig. 14) were almost completely obstructed by alluvial sediments (filling).

The process which led to the formation of the composite conduit of the Buco dei Vinchi cave is very similar to the one proposed by Pasini (1967a, p. 38-40, Figs. 11-13) in order to explain the speleogenesis of the Grotta del Tunnel cave (near Farneto, Bologna: Fig. 2).

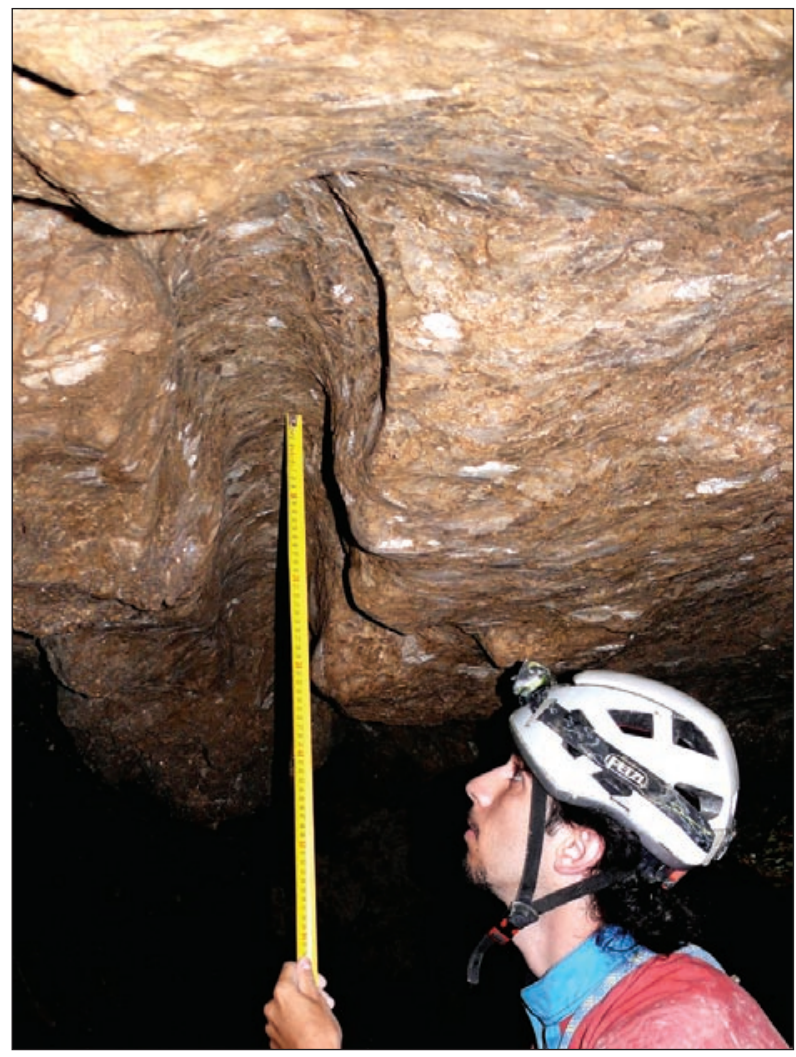

Fig. 17: Small antigravitative ceiling channel with 'reverse U'shaped cross section in the Caverna delle Oreadi (Source: G.S.B. - U.S.B. photographic archives).

\section{VADOSE PHASE F}

After the excavation of component $\delta$ of the composite conduit the piezometric surface dropped, until the stream began flowing in the Buco dei Vinchi cave under vadose conditions and began eroding the filling. Initially the stream was by degrees completely swallowed by the Pozzo delle Ossa pit (Fig. 3), acting as hypogean swallow hole. So the branches of the cave downstream from the Pozzo delle Ossa became hydrologically inactive and were entirely choked by pelites. Then only the upper portion of the filling, down to the present floor of the Cunicolo Meridionale crawl passage, was removed (Fig. 5): so, at the time, the Konvakuationsraum (= part of the cave containing only gas or water) of the Buco dei Vinchi consisted of a crawlway very similar to the present one, and coinciding with components $\gamma$ and $\delta$ 
of the composite conduit. To put it simply, the present crawlway of the Buco dei Vinchi stretched then from the Old entrance of the cave to the mouth of the Pozzo delle Ossa pit (Fig. 3). At that time component antigravitative conduit $\delta$ became a ceiling channel with respect to the crawlway.

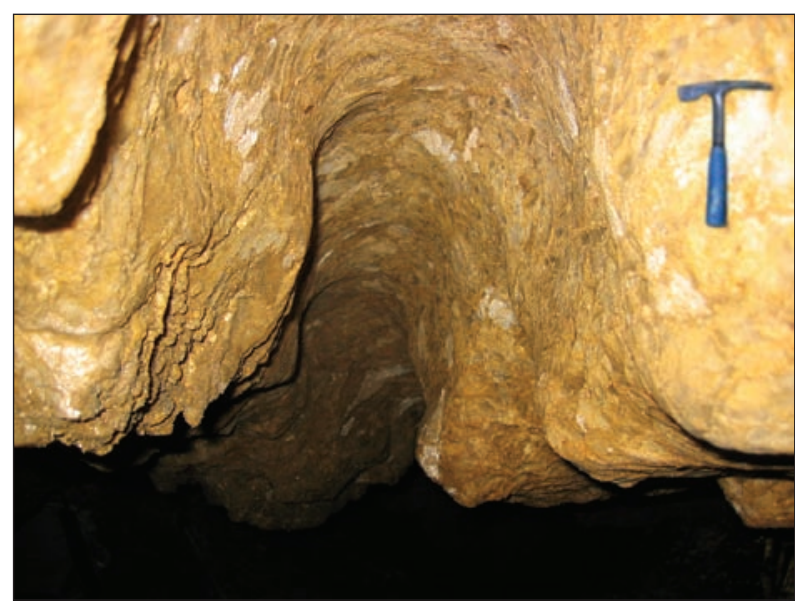

Fig. 18: Other small antigravitative ceiling channel with 'reverse $U$ 'shaped cross section in the Caverna delle Oreadi (Source: G.S.B. - U.S.B. photographic archives).

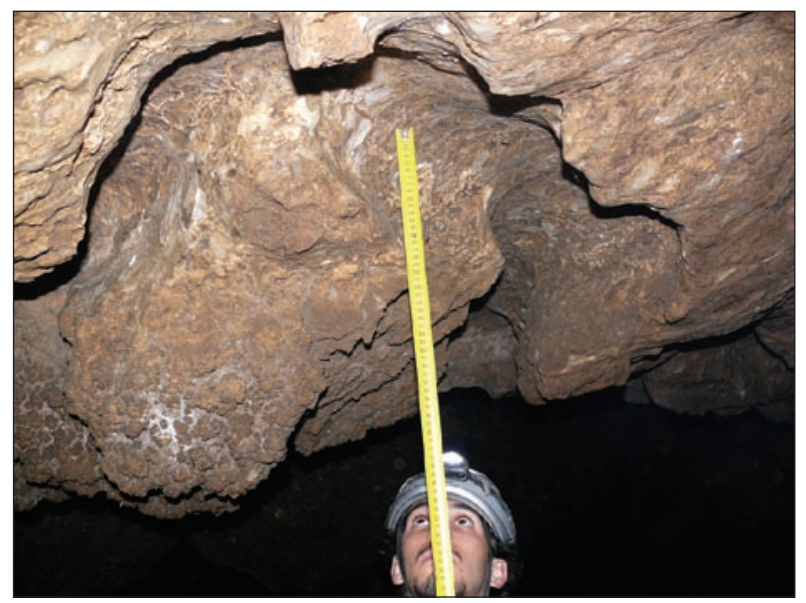

Fig. 19: Meander of a small antigravitative ceiling channel in the Caverna delle Oreadi (Source: G.S.B. - U.S.B. photographic archives).

Afterwards the piezometric surface sank further on. A subsequent, complete swallowing of the hypogean creek took place later further upstream, in the stretch of the crawlway coinciding with the present ceiling channel of the "Caverna delle Oreadi" (Fig. 3: point 1): this caused a further evacuation of the filling and also the erosion of a portion of the Messinian shale interbed in this stretch of the crawlway, which enlarged remarkably and turned into the Caverna delle Oreadi.
At that point the Buco dei Vinchi cave took its present features, and was then transformed from a hydrolog-

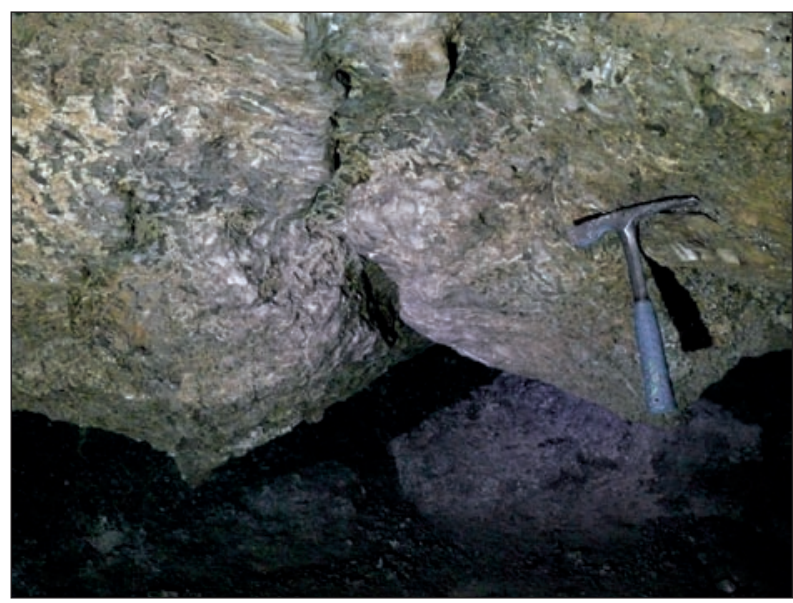

Fig. 20: Small antigravitative ceiling channel developed between two mammelloni in the Caverna delle Oreadi (Source: G.S.B. U.S.B. photographic archives).

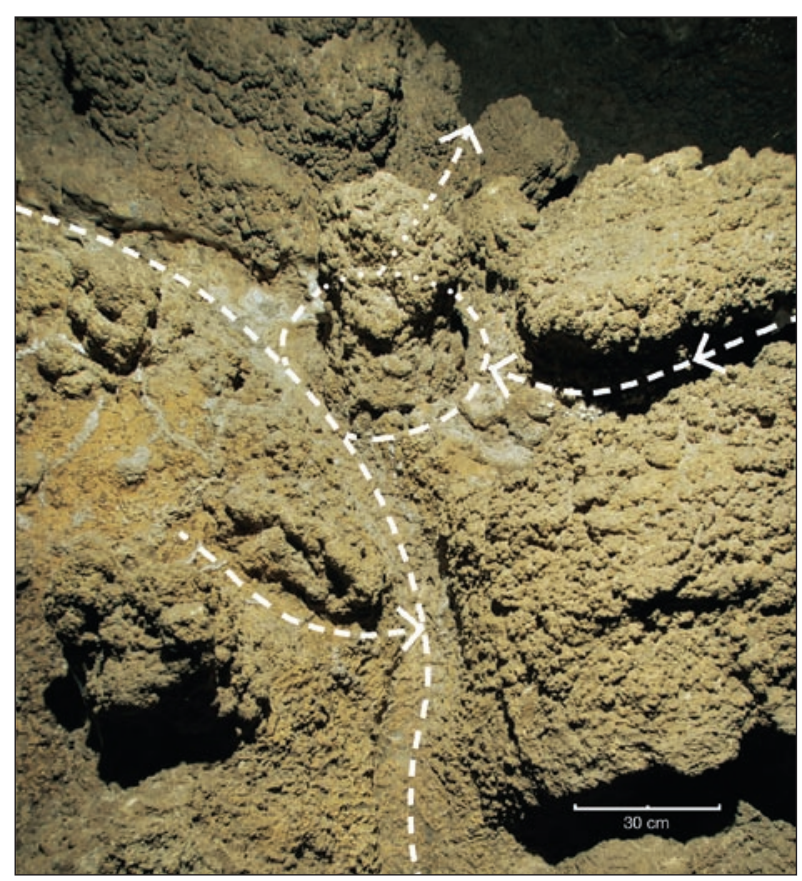

Fig. 21: Example of network of small antigravitative ceiling channels in the eastern side of the Caverna delle Oreadi. The broken lines point out the courses of the ceiling channels. The dotted lines indicate that portions of ceiling channels are hidden by a pendant. The arrows indicate - where possible - the direction of the streams. The ceiling channel closest to the upper margin of the picture flowed into the big composite ceiling channel $(=\alpha+\beta+$ $\gamma+\delta)$ in correspondence of the black zone top right. The main small antigravitative ceiling channel is about $15 \mathrm{~cm}$ wide. The ceiling channels are partially hidden by gypsum efflorescences (Photo: P. Ferrieri, Dipartimento di Scienze della Terra e Geologico-Ambientali of the University of Bologna). 


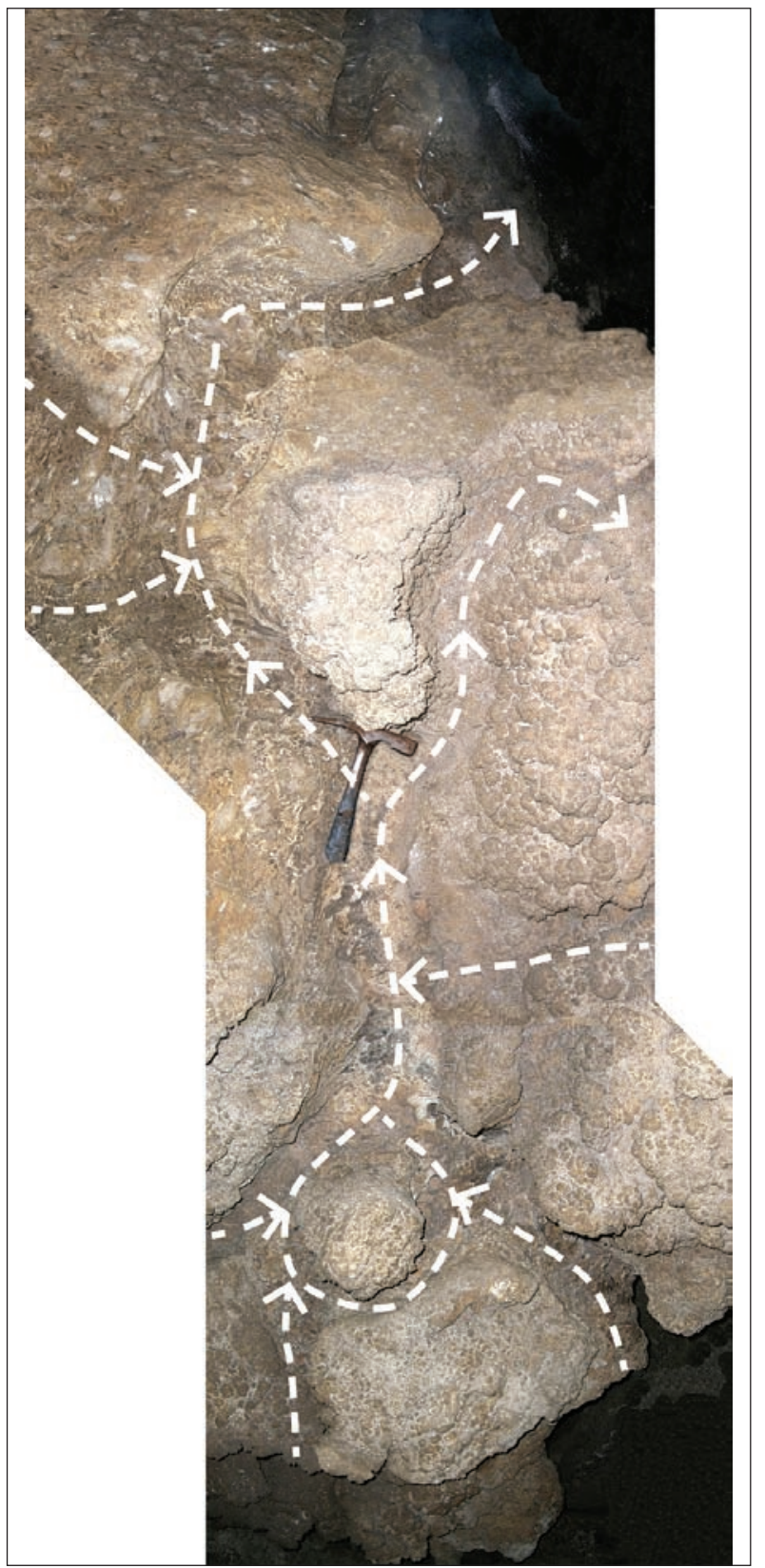

Fig. 22: Another example of network of small antigravitative ceiling channels with pendants, in the eastern side of the "Caverna delle Oreadi". The broken lines point out the courses of the ceiling channels. The arrows indicate the direction of the streams. Also in this case the ceiling channels are partially hidden by gypsum efflorescences. (Photomontage: C. Dalmonte, Dipartimento di Scienze della Terra e Geologico-Ambientali of the University of Bologna).

ically active cave to the dry, inactive cave we can see today; and only at that point the complex of the component conduits $\beta, \gamma$ and $\delta$ became a ceiling channel with respect to the cavern (Fig. 14).

During the vadose erosion the hypogean stream removed part of the filling and of the shale interbed without modifying substantially the speleoforms created by the preceding antigravitative and post-antigravitative erosion: this could be due to the fact that the vadose phase of the Buco dei Vinchi cave was not strong and/or did not last very much.

It should be noted that the composed ceiling channel is the oldest part of the cave.

The sequence of events illustrated above in order to explain the speleogenesis of the composite conduit is the simplest reliable sequence that can be imagined. Actually, this sequence was surely complicated by the reoccurrence of seasonal and non-seasonal piezometric level fluctua-

Fig. 23: Experiment to reproduce in laboratory the degradation of intact micro- and mesocrystalline (crystal size $\leq 1-2 \mathrm{~mm}$ ) gypsum specimens by means of immersion for 84 days in a flow of non-saturated water. a) Shape evolution of a specimen. b) Evolution of the top, medium and bottom diameters of the same specimen. Further explanations in text (Modified from Castellanza of Nova 2009).

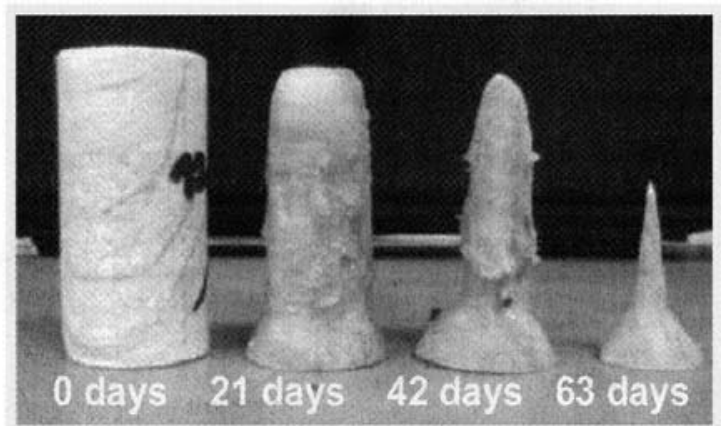

a)

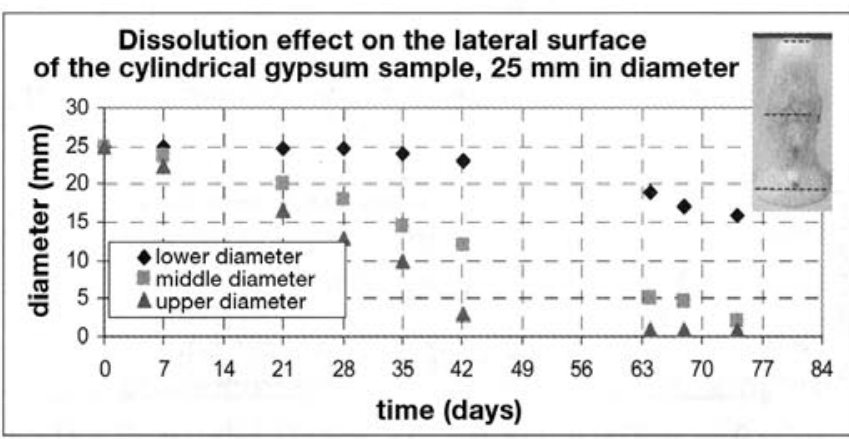

b) 
tions of different amplitude (non-seasonal variations of the piezometric level can be due to variations of the levels of rivers and lakes, to earthquakes, etc.: see Celico 1986, pp. 45-52). Probably repeated phases of sediment evacuation and of re-filling followed each other.

An alternative, simpler hypothesis to explain the development of the composite conduit could be that the rise of the filling was continuous throughout its formation, and that the widening and the narrowing of the walls of the conduit are simply due to variations in stream flow. But this hypothesis is at odds with the shape of the subhorizontal flat ceilings of components $\beta$ and $\gamma$.

A third, simpler hypothesis - hardly believable - for the development of the composite conduit could be that component conduit $\delta$ only formed by antigravitative erosion, whereas components $\gamma, \beta$ and $\alpha$ formed by "normal" erosion (top-down erosion or gravitative erosion) (see Bigot \& Morverand 1994, Fig. 6, modèle $n^{\circ}$ 2).

The simplest hypothesis, that the Caverna delle Oreadi and the Cunicolo Meridionale crawl passage fully developed by gravitative erosion, starting from a phreatic conduit $(\delta)$, is absolutely untenable: in fact, apart from the above mentioned bedding plane between the shale interbed and the gypsum layer (Fig. 15), no other bedding plane nor joint plane nor fault exploitable as guiding fissure (sensu Ford \& Williams 2007, pp. 214) are visible in these cavities.

\section{THE RELIEF INVERSION IN THE MONTE CROARA KARST SUB-AREA}

As mentioned above, the Buco dei Vinchi is certainly one of the oldest caves of the Bologna karst area. The Buco dei Vinchi, when it was hydrologically active, served as a swallow hole of a torrent (or of several rivulets) with a conspicuous (total) flow, judging from the speleoforms visible in the cave and from the alluvial sediments that at present partially fill it. The Buco dei Vinchi entrance is located at the bottom of the very small Dolina dei Vinchi, which is close to the rim of the big Dolina della Spipola (more exactly it is located $13 \mathrm{~m}$ below its rim, and no less than $62 \mathrm{~m}$ above its bottom: Fig. 2). But it is evident - in my opinion - that the entrance of the Buco dei Vinchi swallow hole was once on the bottom of a wide depression (a doline or a blind valley), enormously bigger than the present Dolina dei Vinchi. In my opinion, after the formation of the Buco dei Vinchi cave, a relief inversion took place, that largely demolished the above mentioned wide depression. This relief inversion may have taken several thousand years.

Pasini (1969) carried out paleontological excavations in the filling of the inactive swallow hole of the Cava a Filo quarry (about $300 \mathrm{~m}$ South of the Grotta della Spipola, Fig. 2), not far from the Buco dei Vinchi cave. This swallow hole - largely destroyed by the quarry several years ago - consisted in a pit $11 \mathrm{~m}$ deep, whose rim was located at $230 \mathrm{~m}$ a.s.l.; at the base of the pit there was a little cavern, that turned into a crawl passage - which is the only portion of the swallow hole not destroyed by the quarry we can see today. The pit, the cavern and the crawl passage were completely filled mainly with pelites, containing hundreds of fossil bones, upper Pleistocene in age (Pasini 1969, pp. 32; 1970, pp. 694). Charcoal fragments collected from three layers of the Cava a
Filo inactive swallow hole (the oldest layer was located $150 \mathrm{~cm}$ above the bottom of the filling) yielded $\mathrm{C}^{14}$ ages of $11,150 \pm 650,15,000 \pm 150$ and $18,200 \pm 200$ years BP (Alessio et al.1969, pp. 493-494; Pasini 1970, pp. 692). These three ages are consistent.

Also the cave of the Cava a Filo, when it was hydrologically active, served as swallow hole of a torrent or of several rivulets. In the late 60 s the entrance of this cave (not yet destroyed) was located close to the rim of the Dolina della Spipola, more exactly only a couple of meters below this rim, and no less than $100 \mathrm{~m}$ above the bottom of the doline (Fig. 2). But it is evident that also the entrance of the Cava a Filo swallow hole was, long ago, on the bottom of a wide depression (a doline or a blind valley), later demolished by erosion. This should constitute another proof of the relief inversion mentioned above.

Very likely the earliest caves located at the bottom and on the sides of the original depressions (dolines and blind valleys) were completely choked in time by alluvial sediments, which probably caused the relief inversion in the Monte Croara karst sub-area. In fact the epigean waters were forced by the obstructing fillings to find new, side points of absorption (along bedding planes and fractures) in order to penetrate into the karstic rock; and in correspondence of these new points of absorption secondary dolines and blind valleys formed at lower altitudes.

Therefore, it seems that there it is a certain connection between antigravitative erosion and relief inversion, in the sense that in the karstic areas subject to conspicuous phenomena of hypogean alluviation and antigravitative erosion it is rather likely that relief inversion also takes place. 


\section{RADIOMETRIC AGE DETERMINATIONS OF THE FILLING OF THE “BUCO DEI VINCHI” AND RATE OF GYPSUM EROSION}

Samples for palynological analyses from the clayey-silty wall cut in the filling and located at the base of the Cunicolo Meridionale (Fig. 3: point 2 \& Fig. 6) were collected: these analyses are in progress. Also two thin layers of clay rich in charcoal fragments (undoubtedly belonging to the filling, and not more recent than it) were sampled (Samples BV 10 and BV 20, gathered about $10 \mathrm{~cm}$ and 20 $\mathrm{cm}$ above the base of the wall, respectively).

The two samples containing charcoal fragments were dated by the CEDAD Laboratory (University of Lecce, Italy) by means of the high resolution mass spectrometry technique (AMS). The radiocarbon dates were then calibrated in calendar dates by using the OxCal Ver. 3.10 software, based on atmospheric data (Reimer et al. 2004). The results of the datings and calibrations are shown in Tab. 1. $-3^{\text {rd }}$ hypothesis: the radiocarbon datings of the filling of the Buco dei Vinchi cave are incorrect (probably because the charcoal fragments seem too young), whereas those of the Cava a Filo are correct. Therefore also the filling of the Buco dei Vinchi could be about 18,000 years old.

If one of the two first hypotheses is true, we should admit that only 3,000 years ago near the present ridge of the big Dolina della Spipola - having a maximum diameter of $700 \mathrm{~m}$ and a medium depth of $100 \mathrm{~m} \mathrm{-}$ flowed a stream, capable of choking with its sediments the Buco dei Vinchi swallow hole. Obviously the bottom of this stream and the entrance of the Buco dei Vinchi swallow hole should have been located at that time in a "topographic low", and not close to the ridge of a big doline. It would follow that 3,000 years ago in

Tab. 1: Radiocarbon datings of the 2 samples with charcoal fragments collected from the filling of the "Buco dei Vinchi" cave.

\begin{tabular}{l|c|c|c|c}
\hline Sample & Radiocarbon Age (years BP) & $\delta^{13}$ C (\%o) & Calibrated date (years BC) & Probability \\
\hline BV 20 (CEDAD Code: LTL4432A) & $2768+45$ & - & $1,020-810$ cal BC & $95.4 \%$ \\
\hline BV 10 (CEDAD Code: LTL4433A) & $2820+35$ & $-22.7+0.3$ & $1,120-890 \mathrm{cal} \mathrm{BC}$ & $95.4 \%$ \\
\hline
\end{tabular}

The two datings are consistent, because the stratigraphically lower sample is slightly older. But these ages are heavily at odds with those obtained for the charcoal samples collected in the filling of the Cava a Filo inactive swallow hole (see preceding Chapter), whose excavation was almost surely coeval with that of the Buco dei Vinchi inactive swallow hole. Also these last datings - as written above - are quite consistent, but most of all they are in agreement with the upper Pleistocene age assigned to the filling of the Cava a Filo according to the mammal fauna found in it (Pasini 1969): thus the $C^{14}$ ages of the Cava a Filo - the oldest of which is 18,200 \pm 200 years $\mathrm{BP}$ - are very reliable.

Three hypotheses can be formulated:

$-1^{\text {st }}$ hypothesis: all datings (i.e. both those of the Cava a Filo and those of the Buco dei Vinchi) are correct, and the Cava a Filo swallow hole is much older than the Buco dei Vinchi swallow hole.

$-2^{\text {nd }}$ hypothesis: all datings are correct and the two swallow holes are coeval; but whereas the Cava a Filo swallow hole preserves a filling deposited 11,000 to 18,000 years ago, the Buco dei Vinchi swallow hole was depleted of this filling by vadose waters, and then newly filled with sediments by a stream about 3,000 years ago. place of the big Dolina della Spipola there would have been a "topographic high", and that maybe also the Grotta della Spipola cave - several kilometers long would not yet have been formed. All this could be possible only by admitting that the erosion lato sensu lowered the bottom of the Dolina della Spipola at a mean rate $>33.33 \mathrm{~mm}$ /year: this value is enormously high, but - from a merely experimental point of view - it is not unbelievable, considering the results of a research carried out by Castellanza \& Nova (2009). These authors performed experiments on the degradation of gypsum specimens immersed in a flow of non saturated water (Castellanza \& Nova 2009, pp. 106-108). These specimens - cylinder-shaped, with an height of $50 \mathrm{~mm}$ and a diameter of $25 \mathrm{~mm}$ - consisted of microcrystalline and mesocrystalline gypsum (crystal size $\leq 1-2 \mathrm{~mm}$ ), upper Carnian in age, collected in an artificial tunnel at Santa Brigida (Bergamo, Italy). The specimens were immersed in a container with a capacity of 18 liters; the container was supplied by running water with a flow of $0.75 \mathrm{l} / \mathrm{min}$. ; the water was unsaturated, and had a temperature of $17.5^{\circ} \mathrm{C}$. After 74 days the middle semidiameter of the gypsum cylinders was changed from 12.5 $\mathrm{mm}$ to $1.25 \mathrm{~mm}$ (Fig. 23), with a decrease of $11.25 \mathrm{~mm}$. An erosion of $11.25 \mathrm{~mm}$ in 74 days is equivalent to an erosion of $55.5 \mathrm{~mm} /$ year, almost twice the one hypoth- 
esized above for the Dolina della Spipola; and the selenitic gypsum could have an erosion rate even greater than that of the micro- and mesocrystalline gypsum, given the discontinuities present between its macrocrystals, several centimetres long (Cucchi et al. 1998, pp. 48, wrote: "...in the case of gypsum, when the environmental conditions allow mechanical erosion, the breaking down of larger crystals and their subsequent removal due to erosion may cause a strictly local rapid degradation."). Obviously we have to take into account that the experiment of Castellanza \& Nova (2009) was carried out with a continuous flow of water, contrary to the conditions in the Dolina della Spipola or on other surfaces exposed to the elements.

But the above mentioned purely theoretical hypothesis that the Dolina della Spipola formed in the last 3,000 years is untenable for the following reasons:

a) samples collected from the big calcareous flowstone formation of the Sala del Fango room in the Grotta della Spipola (whose entrance is just at the bottom of the Dolina della Spipola: see Fig. 2) yielded four consistent $\mathrm{U}^{238} / \mathrm{Th}^{236}$ ages of $2,900 \pm 1400$ (?) to 4,600 \pm 300 years BP. Charcoal fragments collected from silty-clayey sediments cropping out just below this flowstone formation yielded a $\mathrm{C}^{14}$ age of 5,300 \pm 60 years BP (Forti 2003, Fig. 14). But, obviously, the Sala del Fango could have been formed, as an isolated chamber, well before the existence of the entire Grotta della Spipola and the Dolina della Spipola.

b) In the Sala Archeologica hall of the Grotta Serafino Calindri (whose entrance is just at the bottom of the Buca del Budriolo blind valley, at a height of $159 \mathrm{~m}$ a.s.l.: Fig. 2) Bardella \& Busi (1972) found numerous remains of a Late Bronze Age settlement, Sub-Apennine Culture, whose age was estimated at 3,000 years BP ca. It follows that about 3,000 years ago the Buca del Budriolo and the Dolina della Spipola - in my opinion coeval - already existed, and had depths close to the present ones.

c) Charcoal fragments from a hearth in the Late Bronze Age settlement of the Sala Archeologica of the Grotta Serafino Calindri yielded $\mathrm{C}^{14}$ ages of $3090 \pm 75$ and $3200 \pm 60$ years BP (Alessio et al.1969, p 484-485). This confirms what stated in point $b$.

d) Measurements with Micro-Erosion Meters (MEM) taken over a period of 2 years at 10 sites in the Monte Croara karst sub-area (Figs. 1 \& 2; annual rain: about $760 \mathrm{~mm}$ ) showed an average surface lowering rate of $-0.79 \mathrm{~mm} /$ year (Cucchi et al. 1998, Table 1), corresponding to about $-2.40 \mathrm{~m}$ in 3,000 years. Cucchi et al. (1998, pp. 48) wrote: "By using all the available data, the gypsum degradation value in the Mediterranean area has been set between $0.4 \mathrm{~mm} / \mathrm{yr}$ and $1.0 \mathrm{~mm} / \mathrm{yr}$."
All this considered, the above mentioned purely theoretical hypothesis that about 3000 years ago in place of the Dolina della Spipola there was a "topographic high", and that this doline formed in the last 3,000 years, is untenable. Likewise untenable is that near the watershed of the big Dolina della Spipola (already formed) about 3,000 years ago flowed a stream, capable of choking the Buco dei Vinchi swallow hole with its sediments: such a stream could only flow in a "topographic low", and not close to the ridge of a doline.

In conclusion, I believe that the above mentioned radiocarbon datings of the Buco dei Vinchi cave are incorrect ( $3^{\text {rd }}$ hypothesis), that the Buco dei Vinchi swallow hole formed long before 3,000 years ago, and that it has, more or less, the same age of the Cava a Filo swallow hole (see Chapter "The relief inversion in the Monte Croara karst sub-area").

As for point d), I have to make two remarks:

1. If we admit simplistically that the average surface lowering rate of the Monte Croara karst sub-area in Late Pleistocene and Holocene was not very different from the present one $(-0.79 \mathrm{~mm} /$ year), we can affirm that the formation of the Dolina della Spipola took at least 127,000 years. That the average surface lowering rate of the Monte Croara karst sub-area did not change sensibly in time is not very likely, owing to the climatic fluctuations of the Late Pleistocene. Yet the above mentioned age of 127,000 years BP seems not to be very far from the truth, considering that Trebbi (1926, pp. 27-28), in a quite independent way (i.e. by calculating the volume of the gypsum yearly eroded from the Dolina della Spipola through a hydrogeologic study of the Risorgente dell'Acquafredda), estimated that the excavation of the Dolina della Spipola took something more than 117,000 years.

However, the aforecited $>127,000$ years BP would not represent the date of the start of the karstic phenomena in the gypsum area near Bologna, but only the date of the beginning of the relief inversion phenomenon (see Chapter "The relief inversion in the Monte Croara karst sub-area"), with excavation of the Dolina della Spipola. Therefore the first karstic phenomena in the Bologna karst area - the ones which gave origin to the probably large Vinchi and Cava a Filo dolines - are very older than 127,000 years BP. In this connection, Forti (2003, pp. 249) affirmed that the karstification of the Bologna karst area started at least 100,000 years BP.

2. The $-0.79 \mathrm{~mm} /$ year lowering represents only the relative altimetrical lowering of the Monte Croara karst sub-area. As for the absolute altimetrical lowering of this zone (with respect to the present sea level), to the above mentioned $-0.79 \mathrm{~mm} /$ year has to be added the 
value of the vertical component of the recent tectonic movements (tectonic uplift), estimated for this area at $+0.4 \mathrm{~mm}$ /year for the last $700 \mathrm{ky}$ (Picotti \& Pazzaglia
2008, Fig. 7). Thus the absolute altimetrical lowering of the Monte Croara karst sub-area (with respect to the present sea level) should be of about $-0.39 \mathrm{~mm} /$ year .

\section{CONCLUSIONS}

To sum up, the "Buco dei Vinchi" cave - one of the oldest caves of the Bologna karst area - underwent six speleogenetic phases:

1) Phreatic phase A: formation of the phreatic protoconduits.

2) Antigravitative erosion phase B: formation of the 'reverse U'- shaped and bulb-shaped small antigravitative conduits + formation of the lowermost part of the big composite conduit (component antigravitative conduit $\alpha$ ), with arched or semicircular vault.

3) Antigravitative erosion + post-antigravitative erosion phase C: formation of the post-antigravitative [erosion] conduit $\beta$, with flat subhorizontal ceiling.

4) Antigravitative erosion + post-antigravitative erosion phase $\mathrm{D}$ : formation of the post-antigravitative [erosion] conduit $\gamma$, with flat subhorizontal ceiling.

5) Antigravitative erosion phase E: formation of antigravitative conduit $\delta$, with arched vault.

6) Vadose phase F: removal of part of the filling and of part of the Messinian shale interbed from the cave (with its transformation in a passable cave), which led to the conversion of the composite conduit originated by antigravitative and post-antigravitative erosion into a ceiling channel.

In the last, vadose phase the stream seems to have mainly removed part of the filling, without noticeably modifying the features created by the former phases.

The entrance of the Buco dei Vinchi cave was once on the bottom of a large depression (a doline or a blind valley), enormously bigger than the present Dolina dei Vinchi.

Very probably after the formation of the Buco dei Vinchi cave a relief inversion took place in this area, starting at least 127,000 years ago; this relief inversion demolished almost completely the Dolina dei Vinchi.

Thus the first karstic phenomena in the Bologna Gypsum karst area are probably very older than 127,000 years BP.

The relative altimetrical lowering of the Monte Croara karst sub-area is $-0.79 \mathrm{~mm} /$ year. Taking into account the tectonic uplift, the absolute altimetrical lowering of the Monte Croara karst sub-area (with respect to the present sea level) should be of about $-0.39 \mathrm{~mm} /$ year.

\section{ACKNOWLEDGEMENTS}

I thank first of all the "Parco Naturale Regionale dei Gessi Bolognesi e Calanchi dell'Abbadessa" for financial support for this research.

I wish to thank also Paolo Grimandi of the G.S.B. - U.S.B. (Gruppo Speleologico Bolognese - Unione Speleologica Bolognese) - the best connoisseur of the karstic phenomena in the neighbourhood of Bologna - for his detailed survey of the "Buco Dei Vinchi" cave and for his precious information about some other gypsum caves. I am grateful to Graziano Agolini, Carlo Correale, Alessandro Gentilini and Lelo Pavanello, more members of the G.S.B. - U.S.B., who helped me much in the field work. I am greatly indebted to Stefano Lugli (Dipartimento di Scienze della Terra of the University of Modena and Reggio Emilia) for his careful revision of the piece of my manuscript concerning the gypsum "mammel- loni". Special thanks are due to Giorgio Bardella and Claudio Busi, and to Stefano Cremonini, Claudio Dalmonte, Paolo Forti, Vincenzo Picotti, Stefano Claudio Vaiani and Giangaspare Zuffa - of the Dipartimento di Scienze della Terra e Geologico-Ambientali of the University of Bologna - for the useful discussions and for their information and suggestions. I thank Michele Sivelli (Istituto Italiano di Speleologia, Bologna) for the bibliographic material placed at my disposal. I thank finally Elzbieta Czerwinska, Cristiano Capelli, Max Cerino and Silvia Tibaldi for their invaluable technical assistance. The colour photographs were taken by Graziano Agolini, Claudio Dalmonte, Paolo Ferrieri and Paolo Grimandi.

The manuscript was revised by Jo De Waele, Paolo Forti and by an anonymous reviewer. 


\section{REFERENCES}

Alessio, M., Bella, F., Cortesi, C. \& B. Turi, 1969: University of Rome Carbon-14 Dates VII.- Radiocarbon, II, 2, 482-498.

Antonioli, N. \& M. Cazzola (eds.),1999: Gessi Bolognesi e Calanchi dell'Abbadessa.- Editrice Compositori, pp. 271, Bologna.

Badino, G., 2009: Postfazione.- In: Dambrosi S. \& R. Semeraro (eds.) Walter Maucci (1922-1995): speleologo scienziato triestino. Scritti memorialistici e celebrativi. - Società Adriatica di Speleoleologia, p. 150, Trieste.

Bardella, G. \& C. Busi, 1972: Testimonianze della Civiltà Subappenninica nella Grotta Serafino Calindri Croara - Bologna.- Speleolologia Emiliana, 7, 2536, Bologna.

Bigot, J.Y. \& P. Morverand, 1994: A propos des canyons dela Cueva Fresca en particulier, et ceux de la Cantabrie en général.- In: Actes $4^{e}$ Rencontre d'Octobre, Spéléo-Club de Paris, September 2003, Pau, 28-37.

Bosák, P., 2003: Karst processes from the beginning to the end: How can they be dated?- Speleogenesis and Evolution of Karst Aquifers. The Virtual Scientific Journal, 1-24.

Bosák, P., 2008: Karst processes and time.- Geologos, 14, $1,19-36$.

Bretz, J.H., 1942: Vadose and phreatic features of limestone caverns.- Journal of Geology, 50, 6, II, 675811.

Calaforra, J. M.,1998: Karstología de yesos.- Ciencia y Tecnologia, Monografías, 3, Universidad de Almería, Servicio de Publicaciones, pp. 389, Almería.

Castellanza, R. \& R. Nova, 2009: Caratterizzazione meccanica di gessi ed anidriti con particolare riferimento a fenomeni degradativi.- In: Nova, R. \& R. Castellanza (eds.) Dissesti indotti dall'alterazione di rocce evaporitiche, Patron, pp. 97-123, Bologna.

Celico, P.,1986: Prospezioni idrogeologiche, Volume Primo.- Liguori, pp. 736, Napoli.

Choppy, J., 2008: Pourqoi se creusent les grottes?.- Karstologia-Mémoires, 16, 1-190.

Cucchi, F., Forti, P. \& F. Finocchiaro, 1998: Gypsum degradation in Italy with respect to climatic, textural and erosional conditions.- Supplementi Geografia Fisica e Dinamica Quaternaria, 3, 4, 41-49.

Demaria, D., 1999: Sviluppo dei fenomeni carsici nei Gessi Bolognesi.- In: Antonioli, N. \& M. Cazzola (eds.) Gessi Bolognesi e Calanchi dell'Abbadessa. Editrice Compositori, pp. 86-91, Bologna.

Dronkert, H., 1976: Late Miocene evaporites in the Sorbas Basin and adjoining areas.- Memore Società Geologica Italiana, 16, 341-361.
Dronkert, H., 1985: Evaporite models and sedimentology of Messinian and Recent evaporites.- GUA Papers of Geology, 1, 24, 1-283.

Fantini, L.,1934: Le Grotte Bolognesi.- Officine Grafiche Combattenti, pp. 71, Bologna.

Farrant, A., 2004: Paragenesis.- In: Gunn, J. (ed.) Encyclopedia of Caves and Karst Science. Fitzroy Dearborn, pp. 569-571, New York.

Farrant, A.R. \& P.L. Smart, 2011: Role of sediments in speleogenesis; sedimentation and paragenesis.Geomorphology,134, 1-2, 79-93.

Ford, D.C., 2000: Speleogenesis Under Unconfined Setting.- In: Klimchouk, A.B., Ford, D.C., Palmer, A.N. \& W. Dreybrodt (eds.) Speleogenesis: Evolution of Karst Aquifers. National Speleological Society, pp. 319-324, Huntsville, Alabama.

Ford, D.C., 2006: Karst geomorphology, caves and cave deposits: A review of North American contributions during the past half century.- In: Harmon, R.S. \& C.M. Wicks (eds.) Perspectives on Karst Geomorphology, Hydrogeology and Geochemistry - A Tribute Volume to D.C. Ford and W.B. White. The Geological Society of America, Special Paper 404, pp. 1-13, Boulder, Colorado.

Ford, D.C. \& P. W. Williams, 1989: Karst Geomorphology and Hydrology.- Academic Division of Unwin Hyman Ltd., pp. 601, London.

Ford, D.C. \& P.W. Williams, 2007: Karst Hydrogeology and Geomorphology.- Wiley \& Sons, pp. 562, Chichester.

Forti, P., 2003: I sistemi carsici.- In: Biancotti, A. \& M. Motta (eds.) Risposta dei processi geomorfologici alle variazioni ambientali. Briganti, pp. 246-251, Genova.

Forti, P., Francavilla, F., Prata, E., Rabbi, E., Veneri, P. \& F. Finotelli, 1985: Evoluzione idrogeologica dei sistemi carsici dell'Emilia-Romagna. 1 - Problematica generale; 2 - Il Complesso Spipola - Acqua Feedda.Regione Emilia - Romagna, Università di Bologna, Tipografia Moderna, pp. 60, Bologna.

Galilei, G.,1612: A Marco Velseri circa le macchie solari, 4 maggio 1612.- In: Flora, F. (ed.)1953: Galileo Galilei: Opere. Ricciardi, pp. XXIX + 1139, Milano.

Goudie, A.S., 2004: Encyclopedia of Geomorphology.Routledge, pp. 1156, New York.

Grimandi, P. \& A. Gentilini, 2009: Banchi, strutture mammellonari e fossili nei gessi del Miocene Superiore.- Sottoterra, 128, 50-71, Bologna. 
Hjulström, F., 1939: Transportation of detritus by moving water.- In: Trask, P. D. (ed.) Recent Marine Sediments.- Special Publication 4, American Association of Petroleum Geologists, pp. 5-31, Tulsa.

Hole, F.D., 1968: Erosion.- In: Fairbridge, R.W. (ed.) The Encyclopedia of Geomorphology. Reinhold Book Corporation, pp. 317-320, New York.

Howell, J.V., 1957: Glossary of Geology and related Sciences.- Williams \& Heinz Lith. Corporation, pp. 325, Washington.

Krause, M., 1999: Lexikon für Höhlenforscher.- Nubuk 99, pp. 214, Bielefeld.

Lauritzen, S. E. \& A. Lauritsen, 1995: Differential diagnosis of paragenetic and vadose canyons.- Cave and Karst Science, 21, 2, 55-59.

Lundberg, J., 2005: Karren.- In: Culver, D.C. \& W.B. White (eds.) Encyclopedia of Caves. Elsevier Academic Press, pp. 315-321, New York.

Monkouse, F. J., 1970: A Dictionary of Geography.- $2^{\text {nd }}$ ed., Edward Arnold Publisher Ltd., pp. 378, London.

Ogniben, L., 1957: Petrografia della Serie Solfifera Siciliana e considerazioni geologiche relative.- Memorie Descrittive della Carta Geologica d'Italia, 33,1-274.

Pasini, G.,1966: I canali di volta nelle grotte carsiche del Bolognese. Nuove ipotesi sulla loro formazione.- Unpublished Graduation Short Experimental Thesis n. ${ }^{\circ}$ 280. Dipartimento di Scienze della Terra e Geologico-Ambientali dell'Università di Bologna, pp. 83.

Pasini, G., 1967a: Osservazioni sui canali di volta delle grotte bolognesi.- Le Grotte d'Italia, 4, 1, 17-74.

Pasini, G., 1967b: Nota preliminare sul ruolo speleogenetico dell'erosione "antigravitativa".- Le Grotte d'Italia, 4, 1, 75-90.

Pasini, G., 1969: Fauna a Mammiferi del Pleistocene superiore in un paleoinghiottitoio carsico presso Monte Croara (Bologna).- Le Grotte d'Italia, 4, 2, $1-46$.

Pasini, G., 1970: Contributo alla conoscenza del tardo Würmiano e del Postwürmiano nei dintorni di Bologna (Italia).- Giorn. di Geol., 36, 2, 687-700.

Pasini, G., 2009: A terminological matter : paragenesis, antigravitative erosion or antigravitational erosion?International Journal of Speleology, 38, 2, 129-138.
Pasini, G., (in preparation): The post-antigravitative erosion (or post-paragenesis).

Picotti, V. \& F.J. Pazzaglia, 2008: A new active tectonic model for the construction of the Northern Apennines mountain front near Bologna (Italy).Journal of Geophysical Research, 113, B08412, doi:10.1029/2007JB005307, 1-24

Plan, L., 2010: Significance of paragenesis in caves of the Eastern Alps.- Geophysical Research Abstracts, 12, EGU 2010, 1.

Reimer, P.J., Baillie, M.G.L., Bard, E., Bayliss, A., Beck, J.W., Bertrand, C.J.H., Blackwell, P.G., Buck, C.E., Burr, G.S., Cutler, K.B., Damon, P.E., Edwards, R.L., Fairbanks, R.G., Friedrich, M., Guilderson, T.P., Hogg, A.G., Hughen, K.A., Kromer, B., McCormac, F.G., Manning, S.W., Ramsey, C.B., Reimer, R.W., Remmele, S., Southon, J.R., Stuiver, M., Talamo, S., Taylor, F.W., Van der Plicht, J. \& C.E. Weihenmeyer, 2004: IntCal04 terrestrial radiocarbon age calibration.- Radiocarbon, 46, 1029-1058.

Renault, Ph., 1958: Eléments de spéléomorphologie karstique.- Annales de. Spéléologie, 13, 1-4, 23-48.

Renault, Ph., 1968: Contribution à l' étude des actions mécaniques et sédimentologiques dans la spéléogenèse. $3^{\mathrm{e}}$ partie: Les facteurs sédimentologiques.Annales de Spéléologie, 23, 3, 529-596.

Šušteršič, F., 2006: Relationships between deflector faults, collapse dolines and collector channel formation: some examples from Slovenia.- International Journal of Speleology, 35,1, 1-12.

Trebbi, G., 1926 : Fenomeni carsici nei gessi emiliani. I. La risorgente dell' "Acqua fredda“.- Giornale di Geologia, 2, 1, 1-35.

Vai, G.B. \& F. Ricci Lucchi,1977: Algal crusts, autochthonous and clastic gypsum in a cannibalistic evaporite basin: a case history from the Messinian Northern Apennines.- Sedimentology, 24, 211-244.

White, W.B., 2007: Evolution and age relations of karst landscapes.- Acta carsologica, 36,1, 45-52.

Zanna, A., 1992: Impressioni sul Buco dei Vinchi.- Sottoterra, 93, 30-31. 